\title{
Analisis Penerapan Sarana Penyelamatan Dan Sistem Proteksi Pasif Terhadap Bahaya Kebakaran (Studi Kasus : Gedung Menara Bosowa Makassar)
}

\author{
Zyulmiangga Rusman ${ }^{1}$, Andi Were Matario ${ }^{2}$, Mardiana Amir ${ }^{3}$, Aisyah Zakaria ${ }^{4}$ \\ ${ }^{1}$ Program Studi D4 Jasa Konstruksi, Jurusan Teknik Sipil \\ ${ }^{2}$ Program Studi D4 Jasa Konstruksi, Jurusan Teknik Sipil \\ ${ }^{3}$ Program Studi D4 Jasa Konstruksi, Jurusan Teknik Sipil \\ ${ }^{4}$ Program Studi D4 Jasa Konstruksi, Jurusan Teknik Sipil \\ Jl. Perintis Kemerdekaan KM. 10 Tamalanrea, Makassar 90245
}

\begin{abstract}
Abstrak-Tujuan penelitian untuk mendapatkan nilai penerapan sarana penyelamatan dan sistem proteksi pasif terhadap bahaya kebakaran dan keandalan sistem keselamatan bangunan terhadap bahaya kebakaran di Gedung Menara Bosowa Makassar dengan mengevaluasi penerapan sistem proteksi kebakaran berdasarkan peraturan yang berlaku.

Adapun komponen utilitas yang akan dianalisis yaitu kelengkapan tapak, sarana penyelamatan, sistem proteksi aktif dan sistem proteksi pasif. Penelitian ini menggunakan metode analisis deksriptif kuantitatif dan teknik pengumpulan data dengan observasi langsung, telaah dokumen dan waancara.Observasi dilakukan dengan menggunakan checklist yang mengacu pada Peraturan Menteri Pekerjaan Umum No.26/PRT/M/2008 sedangkan telaah dokumen menggunakan dokumen-dokumen pendukung yang telah ada di Gedung Menara Bosowa dan wawancara dilakukan dengan mengajukan beberapa pertanyaan pada informan kunci dan informan pendukung.

Hasil penelitian ini menunjukkan penerapan sarana penyelematan dan sistem proteksi pasif terhadap bahaya kebakaran pada Gedung Menara Bosowa berdasarkan hasil pengukuran skala liket dengan jumlah rata-rata 5.00. Nilai tersebut mengkategorikan penerapan sarana penyelematan dan sistem proteksi pasif terhadap bahaya kebakaran pada Gedung Menara Bosowa dalam kategori sangat sesuai dengan Peraturan Menteri Pekerjaan Umum No.26/PRT/M/2008. Sedangkan nilai keandalan sistem keselamatan bangunan terhadap bahaya kebakaran pada Gedung Menara Bosowa berdasarkan Pd-T-112005-C untuk 4 komponen yaitu $88.16 \%$ dari skala $100 \%$. Nilai tersebut menunjukkan bahwa keandalan sistem keselamatan bangunan pada Gedung Menara Bosowa telah sesuai dengan PdT-11-2005-C dan dalam kondisi baik. Peneliti merekomendasikan pihak Gedung Menara Bosowa untuk melengkapi sub komponen sarana penyelamatan, sistem proteksi pasif dan sistem proteksi aktif serta melakukan pemeriksaan, pemeliharaan, pengujian, secara berkala terhadap subkomponen yang telah ada.
\end{abstract}

Kata Kunci: Kebakaran, Proteksi, Keandalan, Gedung

\section{Pendahuluan}

Undang-undang Nomor 28 Tahun 2002 tentang Bangunan Gedung menyatakan bahwa setiap bangunan gedung yang didirikan haruslah memenuhi persyaratan teknis sesuai dengan fungsi bangunan gedung. Persyaratan administrasi meliputi persyaratan status hak atas tanah, status kepemilikan bangunan gedung, dan izin mendirikan bangunan, sementara persyaratan teknis meliputi persyaratan tata bangunan dan persyaratan keandalan bangunan gedung. Undang-undang tersebut juga menjelaskan bahwa setiap bangunan gedung haruslah memenuhi persyaratan keselamatan yang salah satunya meliputi pencegahan dan penanggulangan kebakaran. Pencegahan dan penanggulangan bahaya kebakaran pada bangunan gedung ini dilakukan melalui kelengkapan tapak, sarana penyelamatan, proteksi pasif dan proteksi aktif. Seperti Undang-undang Nomor 28 tahun 2002 tentang Bangunan Gedung, Perda Kota Makassar Nomor 15 tahun 2004 tentang Tata Bangunan juga masyarakat hal dimana diperlukan adanya suatu manajemen penanggulangan kebakaran pada bangunan gedung tertentu.

Provinsi Sulawesi Selatan tepatnya di kota Makassar memiliki potensi kebakaran yang cukup besar. Hal ini terlihat berdasarkan data yang dirilis Dinas Pemadam Kebakaran (Damkar) Makassar yang mencatat adanya peningkatan musibah kebakaran selama tahun 2018.

Sekertaris Dinas Damkar Makassar, Hasanuddin mengungkapkan berdasarkan rekap terjadinya kebakaran 
selama 2018 , setidaknya ada 208 kejadian kebakaran dikota Makassar yang suda ditangani Dinas Damkar Makassar. Jika menilik data jumlah ini mengalami Peningkatan dibandingkan tahun 2017 yang tercatat sebanyak 150 kejadian kebakaran. Sementara untuk taksiran kerugian masyarakat akibat musibah kebakaran diperkirakan mencapai Rp. 20.000.000.000. Sementara untuk masyarakat yang menjadi korban, Dinas Damkar Makassar mencatat ada 10 orang meninggal dunia dan 7 orang mengalami luka (Kabar.news, Sabtu 29/12/2018).

Pembangunan di Kota Makassar dewasanya semakin meningkat, Saat ini banyak pembangunan gedung sebagai pendukung kinerja penduduk di Kota Makassar. Pembangunan gedung yang beragam dan kompleks menuntut aspek keselamatan dan rasa aman terhadap bangunan gedung dan lingkungannya. Salah satu aspek keselamatan yang penting dari sebuah bangunan gedung adalah keselamatan dari bahaya kebakaran.

Salah satu gedung perkantoran dikota Makassar dengan aktivitas dan perilaku yang cukup tinggi yaitu Gedung Menara Bosawa milik Grup Bosowa atau Bosowa Corporation. Menara Bosowa adalah gedung perkantoran tertinggi di Makassar dan Indonesia Timur, dengan 23 lantai 120 meter dan menghadap langsung ke Lapangan Karebosi, serta memiliki jumlah hunian sebanyak 230 hunian hal inilah yang membuat penulis tertarik. Berdasarkan data bangunan diatas tidak menutup kemungkinan akan terjadinya kebakaran yang merupakan suatu permasalahan yang tidak bisa lepas dari manusia, kerugian yang diakibatkan oleh kebakaran tidak hanya berupa kerusakan bangunan saja, melainkan kerugian yang menyangkut moral dan jiwa manusia. Beberapa penyebab kebakaran antara lain : rendahnya pemahaman dan kesadaran akan bahaya kebakaran, kurangnya kesiapan individu untuk menghadapi dan menanggulangi bahaya kebakaran, sistem penanganan kebakaran yang belum terwujud dan terintegrasi serta rendahnya prasarana dan sarana sistem proteksi kebakaran bangunan yang memadai.

Bangunan Gedung Menara Bosowa mestinya memerlukan kelengkapan tapak, sistem proteksi kebakaran dan sarana penyelamatan karena bangunan tersebut memiliki fungsi dan perilaku yang kompleks dalam suatu bangunan tertutup. Berdasarkan hal tersebut, penulis tertarik melakukan penelitian dengan mengangkat judul "Analisis Keandalan Sistem Proteksi terhadap Bahaya Kebakaran (Studi Kasus : Gedung Menara Bosowa)".

Penelitian ini dimaksudkan untuk mengetahui :
1. Bagaimana penerapan sarana penyelamatan dan sistem proteksi pasif terhadap bahaya kebakaran di Gedung Menara Bosowa Makassar?

2. Bagaimana nilai keandalan sistem keselamatan bangunan terhadap bahaya kebakaran di Gedung Menara Bososwa Makassar dengan mengevaluasi penerapan sistem proteksi kebakaran berdasarkan peraturan yang berlaku?

Adapun tujuan dari dilakukannya penelitian ini:

1. Untuk mendapatkan nilai penerapan sarana penyelamatan dan sistem proteksi pasif terhadap bahaya kebakaran di Gedung Menara Bosowa Makassar.

2. Untuk mendapatkan nilai keandalan sistem keselamatan bangunan terhadap bahaya kebakaran di Gedung Menara Bosowa Makassar dengan mengevaluasi penerapan sistem proteksi kebakaran berdasarkan peraturan yang berlaku.

\section{Tinjauan Pustaka}

\section{A. Penelitian Terdahulu}

Penelitian ini dilakukan tidak terlepas dari hasil penelitian-penelitian terdahulu yang pernah dilakukan sebagai bahan perbandingan dan kajian. Adapun hasilhasil penelitian yang dijadikan perbandingan tidak terlepas dari topik penelitian yaitu mengenai penilaian penerapan sarana penyelamatan dan sistem proteksi terhadap bahaya kebakaran.

Berdasarkan penelitian yang dilakukan oleh Lily Christiani P (2011) yang berjudul "Analisis Pelaksanaan Fire Management pada Hotel di Surakarta dengan Mengukur Tingkat Keamanan Hotel”. Hasil penelitiannya menyatakan bahwa penerapan sistem proteksi aktif dan pasif cukup memenuhi syarat sesuai dengan peraturan, analisis penerapan peraturan sistem proteksi aktif dan pasif yang berarti cukup memenuhi peraturan dengan skala likert sebesar 4,232 pelaksanaan pemeriksaan dan pemeliharaan sarana proteksi kebakaran sudah dilakukan dengan rutin, dan ketersediaan alat pemadam kebakaran yang cukup berpengaruh pada keamanaan staff hotel.

Dwiyoga Noris Indrawijaya ( 2011) dengan penelitiannya yang berjudul "Analisis Keandalan Bangunan Gedung (Studi kasus Bangunan Gedung Laboratorium Teknik Fakultas Teknik Unversitas Sebelas Maret Surakarta)". Hasil penelitiannya menyatakan bahwa andal untuk bangunan gedung Laboratorium Teknik Fakultas Teknik Universitas Sebelas Maret Surakarta. Penilaian tingkat keandalan meliputi arsitektur 97,01\% (andal), Strultur 99,24\% 
(andal), Utilitas dan proteksi kebakaran 98,52\% (kurang andal), Aksesibilitas 75,50\% (kurang andal) dan Tata bangunan dan lingkungan 100\% (andal). Untuk meningkatkan dan mempertahankan tingkat keandalan bangunan gedung maka diperlukan perbaikan dan pemeliharaan yang berkelanjutan.

Penelitian mengenai "Analisis Tingkat Kepentingan Persepsi Peng guna Bangunan terhadap Fire Management Rumah Sakit di Kota Surakarta" oleh Rr. Aryu Diah Parwitasari (2010) menyatakan bahwa penerapan sistem proteksi aktif dan pasif cukup memenuhi syarat sesuai dengan peraturan sesuai dengan analisis penerapann peraturan sistem proteksi aktif dan pasif yang menunjukan 3 skala Likert yang berarti cukup memenuhi peraturan, pelaksanaan pemeriksaan dan pemeliharaan sarana proteksi kebakaran sudah dilakukan dengan rutin, dan sarana proteksi yang menurut keluarga pasien dan karyawan RS menjadi prioritas utama untuk dibenahi dan dilengkapi oleh pihak RS.

\section{B. Unsur Penilaian}

1. Penilaian Penerapan Sarana Penyelamatan dan Sistem Proteksi Pasif

Tahapan analisis yang dilakukan dalam penelitian Penilaian Penerapan Sarana Penyelamatan dan Sistem Proteksi Pasif adalah menentukan variabel untuk pengambilan data, pengambilan data dilakukan dengan melakukan interview dan pengamatan langsung di lapangan dengan menggunakan check list.

Tabel 2.1. Gambaran Fokus Penelitian Sarana Penyelamatan

\begin{tabular}{cl}
\hline No & \multicolumn{1}{c}{ Variabel } \\
\hline 1. & Eksit \\
2. & Keandalan jalan keluar \\
3. & Pintu \\
4. & Ruang terlindung dan proteksi tangga \\
5. & Jalan terusan eksit \\
6. & Jumlah sarana jalan ke luar \\
7. & Susunan jalan ke luar \\
8. & Eksit Pelepasan \\
9. & Iluminasi sarana jalan ke luar \\
10. & Pencahayaan darurat \\
11. & Penandaan sarana jalan ke luar \\
\hline
\end{tabular}

Sumber : Permen PU No.26/PRT/M/2008
Tabel 2.2 Gambaran Fokus Penelitian Sistem Proteksi Pasif

\begin{tabular}{cl}
\hline No & \multicolumn{1}{c}{ Variabel } \\
\hline 1. & Pasangan konstruksi tahan api \\
2. & Pintu dan jendela tahan api \\
3. & Bahan pelapis interior \\
4. & Penghalang api \\
5. & Partisi penghalang asap \\
6. & Penghalang asap \\
7. & Atrium \\
\hline Sumber $:$ Permen $P U$ No:26/PRT/M/2008
\end{tabular}

Tabel 2.3 Checklist Pengamatan Di Lapangan

\begin{tabular}{ccccc}
\hline No & \multirow{2}{*}{ Variabel } & \multicolumn{2}{c}{ Kondisi } & \multirow{2}{*}{ Keterangan } \\
. & & Ya Ada & Tidak & Ya \\
\hline 1. & Eksit & Ya & - & \\
2. & Keandalan & Ya & - & \\
3. & jalan keluar & & & \\
\hline
\end{tabular}

Hasil dari pengamatan, selanjutnya di analisis berdasarkan skala likert yakni skala sebagai pengukuran kesesuaian antara dua atau lebih komponen yang ditinjau.

Tabel 2.4 Skala Likert

\begin{tabular}{clc}
\hline No. & \multicolumn{1}{c}{ Keterangan } & Skala likert \\
\hline 1. & Sangat sesuai dengan peraturan & 5 \\
2. & Sesuai dengan peraturan & 4 \\
3. & Cukup sesuai dengan peraturan & 3 \\
4. & Kurang sesuai peraturan & 2 \\
5. & Sangat tidak memenuhi & 1 \\
\hline \multicolumn{2}{l}{ Sumber : Sugiyono, 2009 }
\end{tabular}

Untuk mendapatkan hasil final setiap komponen, digunakan rumus rata - rata sebagai berikut.

$$
\begin{aligned}
& \text { Rata }- \text { rata }=\frac{\text { Jumlah nilai nilai }}{\text { banyak data } X} \\
& X=\frac{x_{1}+x_{2}+\ldots+x[\text { [ }}{n} \quad \ldots . . . . . \text { (2.1.) }
\end{aligned}
$$

2. Penilaian Nilai Keandalan Sistem Keselamatan Bangunan (NKSKB)

Tahapan analisis yang dilakukan dalam Penilaian Nilai Keandalan Sistem Keselamatan Bangunan Gedung adalah dengan meninjau secara langsung keadaan sebenarnya di lapangan, selanjutnya dianalisis dengan menggunakan standar dan peraturan yang berlaku. 
Keandalan merupakan tingkat kesempurnaan kondisi perlengkapan proteksi yang menjamin keselamatan, fungsi dan kenyamanan suatu bangunan gedung dan lingkungannya selama masa pakai dari gedung tersebut dari segi bahayanya terhadap kebakaran. Keselamatan gedung merupakan kondisi yang menjamin keselamatan dan tercegahnya bencana dalam suatu gedung beserta isinya (manusia, peralatan, barang) yang diakibatkan oleh kegagalan atau tidak berfungsinya utilitas gedung. (Peraturan $\mathrm{Pd}-\mathrm{T}-$ 11-2005-C tentang Pemeriksaan Keselamatan Kebakaran Bangunan Gedung)

Tabel 2. 5 Gambaran Fokus Penelitian Nilai Keandalan Sistem Keselamatan Bangunan

\begin{tabular}{|c|c|}
\hline No & Variabel \\
\hline \multicolumn{2}{|r|}{ Kelengkapan Tapak } \\
\hline 1. & Sumber Air \\
\hline 2. & Jalan Lingkungan \\
\hline 3. & Jarak Antar Bangunan \\
\hline 4. & Hidran Halaman \\
\hline \multicolumn{2}{|r|}{ Sarana penyelamatan } \\
\hline 1. & Jalan Keluar \\
\hline 2. & Konstruksi Jalan ke Luar \\
\hline 3. & Landasan Helikopter \\
\hline \multicolumn{2}{|r|}{ Sarana Proteksi Aktif } \\
\hline 1. & Deteksi dan Alarm \\
\hline 2. & Siemes Conection \\
\hline 3. & Pemadam Api Ringan \\
\hline 4. & Hidran Gedung \\
\hline 5. & Sprinkler \\
\hline 6. & Sistem Pemadam Luapan \\
\hline 7. & Pengendali Asap \\
\hline 8. & Deteksi Asap \\
\hline 9. & Pembuangan Asap \\
\hline 10. & Lift Kebakaran \\
\hline 11. & Cahaya Darurat \\
\hline 12. & Listrik Darurat \\
\hline 13 & Ruang Pengendalian Operasi \\
\hline \multicolumn{2}{|r|}{ Sistem Proteksi Pasif } \\
\hline 1 & Ketahanan api struktur bangunan \\
\hline 2 & Kompartemenisasi ruang \\
\hline 3 & Perlindungan bukaan \\
\hline
\end{tabular}

Kondisi setiap komponen atau bagian bangunan harus dinilai atau dievaluasi. Nilai kondisi komponen proteksi kebakaran bangunan dibagi dalam tiga tingkat, yaitu : BAIK="B" ; SEDANG atau CUKUP $=$ "C" dan KURANG = "K" (Ekuivalensi nilai B adalah 100, C adalah 80 dan $\mathrm{K}$ adalah 60 ).
Penilaian didasarkan pada kriteria atau pembatasan kondisi komponen bangunan. (Peraturan $\mathrm{Pd}-\mathrm{T}-11-2005-\mathrm{C}$ tentang Pemeriksaan Keselamatan Kebakaran Bangunan Gedung)

Tabel 2. 6 Tingkat penilaian audit kebakaran

\begin{tabular}{|c|c|c|}
\hline Nilai & Kesesuaian & Keandalan \\
\hline \multicolumn{2}{|c|}{$>80-100$ Sesuai persyaratan } & Baik (B) \\
\hline $60-80$ & $\begin{array}{l}\text { Terpasang tetapi ada } \\
\text { sebagian kecil } \\
\text { instalasi yang tidak } \\
\text { sesuai persyaratan }\end{array}$ & Cukup (C) \\
\hline$<60$ & $\begin{array}{l}\text { Tidak sesuai sama } \\
\text { sekali }\end{array}$ & Kurang (K) \\
\hline
\end{tabular}

Sumber : Peraturan Pd-T-11-2005-C tentang Pemeriksaan Keselamatan Kebakaran Bangunan Gedung

Tabel 2.7 Hasil Pembobotan Parameter Komponen Sistem Keselamatan Bangunan

\begin{tabular}{cl}
\hline No. & \multicolumn{1}{c}{ Parameter KSKB } \\
\hline 1 & Kelengkapan Tapak \\
2 & Sarana Penyelamatan \\
3 & Sistem Proteksi Aktif \\
4 & Sistem Proteksi Pasif \\
\hline Sumber : Peraturan Pd-T-11-2005-C tentang \\
Pemeriksaan Keselamatan Kebakaran \\
Bangunan Gedung
\end{tabular}

Klasifikasi tingkat keandalan keselamatan bangunan

a. Baik, bila nilai NKSKB tidak kurang antara $80 \%-100 \%$.

b. Cukup baik, bila $60 \%<$ NKSKB $<80 \%$

c. Kurang, bila NKSKB $<60 \%$

Cara Pengisian dan Pengolahan hasil pemeriksaan dan pencatatan kondisi nyata komponen utilitas digunakan untuk proses pengolahan dan penentuan nilai keandalan utilitas.

Tabel 2. 8 Penilaian Komponen Keselamatan Bangunan

\begin{tabular}{|c|c|c|c|c|c|c|}
\hline No & $\begin{array}{c}\text { KSKB/ } \\
\text { Sub } \\
\text { KSKB }\end{array}$ & $\begin{array}{c}\text { Hasil } \\
\text { Penilaian }\end{array}$ & $\begin{array}{l}\text { Standar } \\
\text { Penilaian }\end{array}$ & Bobot & $\begin{array}{c}\text { Nilai } \\
\text { Kondisi }\end{array}$ & $\begin{array}{c}\text { Jumlah } \\
\text { Nilai }\end{array}$ \\
\hline 1 & 2 & 3 & 4 & 5 & 6 & 7 \\
\hline
\end{tabular}


Beberapa langkah pengisian form penilaian komponen keselamatan bangunan :

1. Kolom 1, berisi nomor penilaian

2. Kolom 2, berisi variable komponen keselamatan bangunan

3. Kolom 3, menuliskan hasil penilaian sesuai dengan pengamatan langsung. Penilaian berupa disajikan dalam bentuk huruf $\mathrm{B}, \mathrm{C}$, atau K

4. Kolom 4, menuliskan penilaian dari kolom 3 yang disajikan dalam bentuk Angka.

5. Kolom 5, menuliskan bobot tiap komponen.

6. Kolom 6, menuliskan nilai kondisi dengan rumus :

\section{Nilai kondisi $=($ kolom 4) $\times($ kolom 5$) \times$ (bobot tiap komponen)............... (2.2.)}

\section{Metode Penelitian}

\section{A. Lokasi Penelitian}

Penelitian dilakukan di Gedung Perkantoran Menara Bosowa, Jl. Jend. Sudirman No.7, Pisang Utara, Kec. Ujung Pandang Kota Makassar, Sulawesi Selatan.

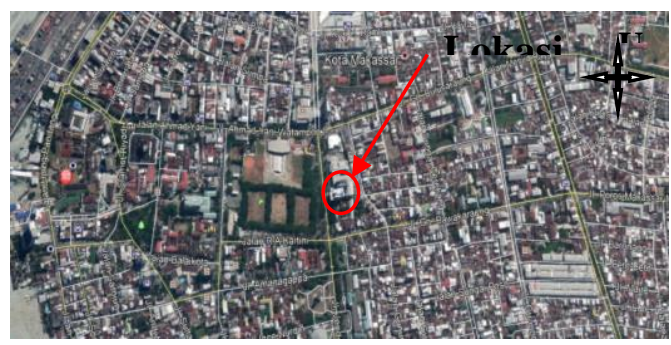

Gambar 3.1. Lokasi Penelitian

\section{B. Waktu Penelitian}

Sasaran objek penelitian adalah pihak - pihak yang bersangkutan di bidang kebakaran. Pengambilan data dilakukan diluar jam kerja, dan penelitian dilakukan pada bulan Februari 2020 - September 2020

\section{Teknik Pengumpulan Data}

Teknik pengumpulan data pada penelitian ini menggunakan 2 cara, yaitu;

1. Data primer

Data primer diperoleh dari observasi langsung dan wawancara mengenai sistem proteksi kebakaran di Gedung Menara Bosowa. Observasi dilakukan dengan menggunakan cheklist yang mengacu pada peraturan Menteri Pekerjaan Umum No.
26/PRT/M/2008 dan Pd-T-11-2005-C tentang Pemeriksaan Keselamatan Kebakaran Bangunan Gedung.

2. Data sekunder

Data sekunder diperoleh dari beberapa peraturan, antara lain;

a. Peraturan Menteri Pekerjaan Umum No. 26/PRT/M/2008,

b. Pd-T-11-2005-C tentang Pemeriksaan Keselamatan Kebakaran Bangunan Gedung,

c. Profil Gedung Menara Bosowa Jl. Jend. Sudirman No. 7, Pisang Utara, Kec. Ujung Pandang Kota Makassar, Sulawesi Selan.

d. Dokumen-dokemen Pendukung terlampir

\section{Metode Analisis Data}

Seluruh data yang diperoleh dalam penelitian akan diolah dan dianalisis dengan langkah-langkah sebagai berikut:

1. Mengumpulkan seluruh data untuk setiap subkomponen-subkomponen yang diperoleh melalui metode-metode pengumpulan yang sudah ditetapkan. Subkomponen dalam penelitian ini adalah subkomponen keandalan sistem keselamatan bangunan (Sub KSKB) yang sudah ditetapkan dalam pedoman pemeriksaan keselamatan kebakaran bangunan gedung pd-t-11-2005-c dan berdasarkan Peraturan Menteri Pekerjaan Umum No:26/PRT/M/2008 untuk selanjutnya di analisis berdasarkan skala likert.

2. Metode pertama yang digunakan dalam pengumpulan data adalah observasi langsung. Data yang tidak bisa diperoleh melaui observasi atau data yang hanya dapat diambil melalui catatan dokumen dikumpulkan melalui telaah dokumen. Data yang tidak bisa diperoleh melaui observasi dan telaah dokumen atau data yang hanya dapat diambil melalui proses wawancara dikumpulkan melalui kegiatan wawancara dengan informan

3. Data disusun dan dikelompokkan sesuai dengan variabel komponen-komponen sistem proteksi kebakaran bangunan gedung.

4. Mencocokkan data yang diperoleh dengan standar pedoman teknis pemeriksaaan keselamatan kebakaran bangunan gedung yang dibuat oleh departemen PU. Hasil perbandingan akan menghasilkan nilai kualitatif berupa B (baik), C (cukup), dan K (kurang).

5. Subkomponen yang mendapat nilai $\mathrm{B}$ akan diberikan nilai kuantitatif $>80-100$, nilai $\mathrm{C}$ akan diberikan nilai kuantitatif $60-80$, dan nilai $\mathrm{K}$ akan diberikan nilai kuantitatif $<60$. Hasil temuan yang diperoleh peneliti melalui observasi langsung akan dicocokkan dengan 
kriteria yang ada. Jika terdapat kriteria yang tidak dapat diperoleh dengan observasi, maka penentuan pemenuhan kriteria tersebut akan dilakukan melalui metode wawancara atau telaah dokumen.

6. Seluruh hasil temuan kemudian akan dicocokkan dengan kriteria-kriteria yang telah ditentukan hasil pencocokkan kemudian dikonsultasikan kepada pihak/petugas/tenaga ahli yang memiliki kualifikasi dalam peraturan proteksi kebakaran bangunan gedung. Peneliti bersama pihak/petugas/tenaga ahli tersebut melakukan diskusi untuk menentukan nilai kuantitatif $(<60,60-80$, dan $>80-100)$ bagi setiap subkomponen yang telah diperiksa oleh peneliti. Konsultasi dan diskusi tersebut dilakukan untuk menghindari subjektifitas penilaian.

7. Adapun yang menjadi bahan pertimbangan dalam menentukan nilai kuantitatif untuk setiap subkomponen tersebut adalah terkait seberapa banyak kriterian-kriteria yang sudah terpenuhi oleh masingmasing subkomponen.

8. Mengkalikan nilai kuantitaif tersebut dengan bobot subkomponen KSKB dan bobot komponen KSKB.

9. Bobot subkomponen kskb dan bobot komponen KSKB yang dimaksud dalam poin 7 sudah ditentukan dalam pedoman pemeriksaan keselamatan kebakaran bangunan gedung pd-t-11-2005-c yang digunakan dalam penelitian ini.

10.Penghitungan antara nilai kuantitatif subkomponen dengan bobot subkomponen KSKB dan bobot komponen KSKB akan menghasilkan nilai kondisi setiap subkomponen (dengan satuan persentase).

11.Perhitungan poin 3 sampai 9 dilakukan untuk setiap subkomponen. Seluruh nilai kondisi subkomponen pada masing-masing komponen kemudian dijumlahkan. Angka yang didapatkan merupakan nilai komponen sistem proteksi kebakaran (dengan satuan persentase).

12.Nilai keempat komponen lalu dijumlahkan dan menghasilkan nilai Kuantitatif keandalan sistem proteksi kebakaran (dengan satuan persentase).

13. Nilai yang didapat kemudian diubah ke dalam nilai kualitatif

14.Jika tingkat nilai Keandalan Sistem Proteksi Kebakaran $\geq \mathbf{8 0} \%-100 \%$, maka diberi nilai kualitatif B

15.Jika jumlah nilai keandalan sistem proteksi kebakaran $\geq \mathbf{6 0} \%-<80 \%$, maka diberi nilai kualitatif C Dan jika nilai tingkat keandalan sistem proteksi kebakaran kurang dari $60 \%$, maka diberi nilai kualitatif $\mathrm{K}$ (kurang).
Diagram Alir Metode Penelitian

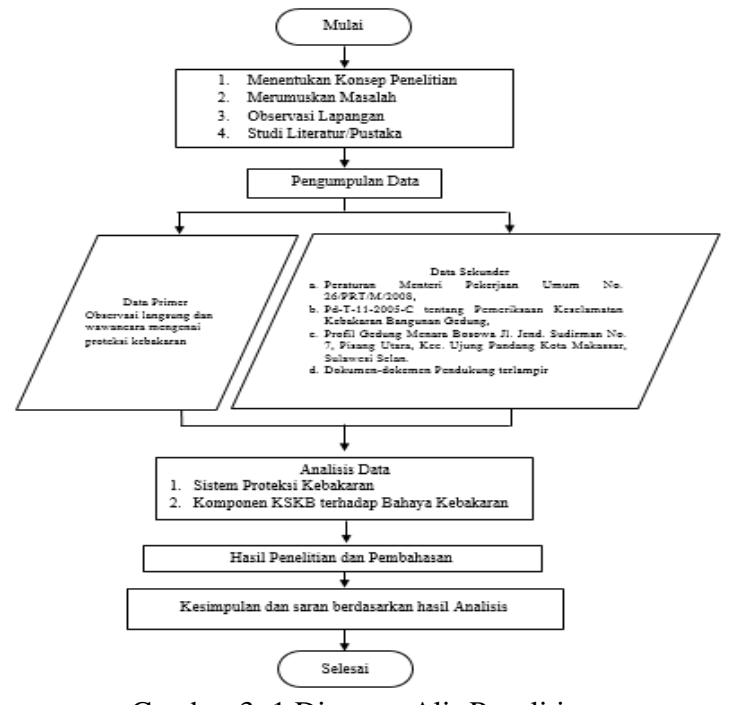

Gambar 3. 1 Diagram Alir Penelitian

\section{Hasil dan Pembahasan}

\section{A. Analisis Deskriptif}

Analisis deskriptif ini berdasarkan hasil dari check list pengamatan di lapangan mengenai sarana penyelamatan dan sistem proteksi pasif. Check list dilakukan di Gedung Menara Bosowa. Hasil check list bisa dilihat di Lampiran.

Berdasarkan hasil check list dari pengamatan, selanjutnya di analisis berdasarkan skala likert yakni skala sebagai pengukuran kesesuaian antara dua atau lebih komponen yang ditinjau.

1. Sarana penyelamatan

Hasil pengamatan mengenai sarana penyelamatan berdasarkan pengamatan di lapangan, disajikan dalam tabel berikut :

Tabel 4. 1 Eksit

\begin{tabular}{|c|c|c|}
\hline Peraturan & $\begin{array}{l}\text { Kondisi } \\
\text { Existing }\end{array}$ & $\begin{array}{l}\text { skala } \\
\text { likert }\end{array}$ \\
\hline $\begin{array}{l}\text { Eksit dipisahkan dari } \\
\text { bangunan lain (Permen PU } \\
\text { No:26/PRT/M/2008 :35) }\end{array}$ & $\begin{array}{l}\text { Dipisahkan } \\
\text { oleh koridor }\end{array}$ & 5 \\
\hline $\begin{array}{l}\text { Pemisah dibangun dengan } \\
\text { pasangan konstruksi yang } \\
\text { tidak mudah terbakar } \\
\text { (Permen PU } \\
\text { No:26/PRT/M/2008 : 36) }\end{array}$ & $\begin{array}{l}\text { Pemisah } \\
\text { dari } \\
\text { Kontruksi } \\
\text { beton }\end{array}$ & 5 \\
\hline
\end{tabular}


Tabel 4. 2 Keandalan Jalan Keluar

\begin{tabular}{|c|c|c|}
\hline Peraturan & $\begin{array}{l}\text { Kondisi } \\
\text { Existing }\end{array}$ & $\begin{array}{l}\text { skala } \\
\text { likert }\end{array}$ \\
\hline $\begin{array}{l}\text { Perabot, dekorasi, atau benda- } \\
\text { benda lain tidak boleh diletakkan } \\
\text { disepanjang eksit (Permen PU } \\
\text { No:26/PRT/M/2008:39) }\end{array}$ & $\begin{array}{l}\text { Tidak ada } \\
\text { sepanjang } \\
\text { eksit }\end{array}$ & 5 \\
\hline $\begin{array}{l}\text { Tidak boleh ada sandaran, pagar, } \\
\text { penghalang atau pintu } \\
\text { disepanjang eksit (Permen PU } \\
\text { No:26/MRT/M/2008:39) }\end{array}$ & $\begin{array}{l}\text { Tidak ada } \\
\text { penghalang }\end{array}$ & 5 \\
\hline $\begin{array}{l}\text { Cermin tidak boleh dipasang di } \\
\text { pintu eksit (Permen PU } \\
\text { No:26/PRT/M/2008 : 39) }\end{array}$ & $\begin{array}{l}\text { Tidak ada } \\
\text { cermin } \\
\text { dipintu eksit }\end{array}$ & 5 \\
\hline $\begin{array}{l}\text { Setiap pintu dan jalan masuk } \\
\text { untuk eksit, jelas dan langsung } \\
\text { (Permen PU No:26/PRT/M/ } \\
2008: 39 \text { ) }\end{array}$ & $\begin{array}{l}\text { Pintu dan } \\
\text { akses jalan } \\
\text { keluar jelas }\end{array}$ & 5 \\
\hline \multicolumn{3}{|l|}{ Tabel 4. 3 Pintu } \\
\hline Peraturan & $\begin{array}{l}\text { Kondisi } \\
\text { Existing }\end{array}$ & $\begin{array}{l}\text { skala } \\
\text { likert }\end{array}$ \\
\hline $\begin{array}{l}\text { Pintu pada sarana jalan keluar } \\
\text { dari jenis engsel sisi atau pintu } \\
\text { ayun (Permen PU } \\
\text { No:26/PRT/M/2008 :39) }\end{array}$ & $\begin{array}{l}\text { Pintu dari } \\
\text { engsel sisi }\end{array}$ & 5 \\
\hline $\begin{array}{l}\text { Pintu tahan api membuka } \\
\text { ke arah jalur jalan keluar } \\
\text { (Permen PU No:26/PRT/M/ } \\
2008: 41 \text { ) }\end{array}$ & $\begin{array}{l}\text { Pintu besi } \\
\text { membuka ke } \\
\text { jalan keluar }\end{array}$ & 5 \\
\hline $\begin{array}{l}\text { Semua tangga yang melayani } \\
\text { sebuah eksit harus tertutup } \\
\text { (Permen } \\
\text { PU No:26/PRT/M/2008: }: 50 \text { ) }\end{array}$ & $\begin{array}{l}\text { Semua } \\
\text { tangga } \\
\text { keadaan } \\
\text { tertutup }\end{array}$ & 5 \\
\hline
\end{tabular}

Tabel 4. 4 Ruang Terlindung dan Proteksi Tangga

\begin{tabular}{ccc}
\hline \multirow{2}{*}{ Peraturan } & Kondisi & skala \\
& Existing & likert \\
\hline
\end{tabular}

Penandaan jalur tangga menunjukkan tingkat lantai, Penandaan akhir teratas dan terbawah tangga dari ruang terlindung (Permen PU No:26/PRT/M/2008 : 53)

Penandaan ditempatkan mendekati $1,5 \mathrm{~m}$ di atas bordes lantai, posisi mudah terlihat (Permen PU menunjukkan tingkat lantai

Jarak penandaan diatas bordes

No:26/PRT/M/2008 : 54)

Penandaan dicat atau dituliskan pada dinding dan terpasang kuat(Permen PU No:26/PRT/M /2008:54) lantai

Penandaan dicetak dan terpasang kuat

huruf identifikasi jalur tangga ditempatkan di bagian atas dengan tinggi minimum huruf $2,5 \mathrm{~cm}$ Tinggi huruf 3 $\mathrm{cm}$

(Permen PU

No:26/PRT/M/2008:55)

\begin{tabular}{lll}
\hline \multicolumn{3}{c}{ Tabel 4. 5 Jalan Terusan Eksit } \\
\hline \multirow{2}{*}{ Peraturan } & Kondisi & skala \\
& Existing & likert
\end{tabular}

Jalan terusan eksit memiliki

tingkat ketahanan api Jalan terusan

(Permen PU

eksit dari beton

5

No:26/PRT/M/2008 : 58)

Tabel 4. 6 Jumlah Sarana Jalan Keluar

\begin{tabular}{llc}
\hline \multicolumn{1}{c}{ Peraturan } & \multicolumn{1}{c}{$\begin{array}{c}\text { Kondisi } \\
\text { Existing }\end{array}$} & $\begin{array}{l}\text { skala } \\
\text { likert }\end{array}$ \\
\hline Jumlah minimim sarana & Jumlah & \\
jalan keluar dari setiap & sarana jalan & \\
balkon, lantai, adalah dua & keluar & 5 \\
(Permen PU No:26/PRT/M & terdapat dua & \\
/2008:70) & & \\
\hline
\end{tabular}

Tabel 4. 7 Susunan Jalan Keluar

\begin{tabular}{llc}
\hline \multicolumn{1}{c}{ Peraturan } & $\begin{array}{l}\text { Kondisi } \\
\text { Existing }\end{array}$ & $\begin{array}{l}\text { skala } \\
\text { likert }\end{array}$ \\
\hline $\begin{array}{l}\text { Eksit ditempatkan dan } \\
\text { disusun sehingga eksit } \\
\text { mudah dicapai pada setiap }\end{array}$ & $\begin{array}{l}\text { Eksit mudah } \\
\text { dicapai }\end{array}$ & 5 \\
saat (Permen PU & & \\
No:26/PRT/M/2008 : 72) & & \\
\hline
\end{tabular}


Tabel 4. 8 Susunan Jalan Keluar

\begin{tabular}{llc}
\hline \multicolumn{1}{c}{ Peraturan } & \multicolumn{1}{c}{$\begin{array}{c}\text { Kondisi } \\
\text { Existing }\end{array}$} & $\begin{array}{c}\text { skala } \\
\text { likert }\end{array}$ \\
\hline $\begin{array}{l}\text { Akses eksit tidak melalui } \\
\text { dapur, gudang, ruang }\end{array}$ & $\begin{array}{l}\text { Akses tidak } \\
\text { melalui ruang } \\
\text { terkunci }\end{array}$ \\
$\begin{array}{l}\text { istirahat, ruang kerja, } \\
\text { kloset, atau ruang lain } \\
\text { yang mungkin terkunci }\end{array}$ & 5 \\
Permen PU & \\
No:26/PRT/M/2008 : 81) & \\
Gantungan atau gorden & Tidak terdapat & \\
tidak & gantungan & \\
dipasang di atas pintu & dipintu eksit & 5 \\
eksit (Permen & \\
PU No:26/PRT/M/2008: & \\
81) & & \\
\hline
\end{tabular}

Tabel 4. 9 Eksit Pelepasan

\begin{tabular}{llc}
\hline \multicolumn{1}{c}{ Peraturan } & \multicolumn{1}{c}{$\begin{array}{c}\text { Kondisi } \\
\text { Existing }\end{array}$} & $\begin{array}{c}\text { skala } \\
\text { likert }\end{array}$ \\
\hline $\begin{array}{l}\text { Semua eksit berakhir } \\
\text { langsung di jalan umum } \\
\text { atau pada bagian luar } \\
\text { eksit pelepasan (Permen }\end{array}$ & $\begin{array}{l}\text { Eksit berakhir } \\
\text { pada bagian }\end{array}$ & $\begin{array}{l}\text { luar eksit } \\
\text { pelepasan }\end{array}$ \\
$\begin{array}{l}\text { PU No:26/PRT/M/2008 : } \\
\text { 85) }\end{array}$ & 5 \\
$\begin{array}{l}\text { Eksit pelepasan ditata dan } \\
\text { diberi } \\
\text { tanda untuk membuat }\end{array}$ & \\
jelas arah dari jalan ke & $\begin{array}{l}\text { Tanda arah } \\
\text { luar ke jalan umum } \\
\text { tPermen PU }\end{array}$ & 5 \\
$\begin{array}{l}\text { No:26/PRT/M/2008 } \\
\text { 87) }\end{array}$ & \\
\hline
\end{tabular}

Tabel 4. 10 Iluminasi Sarana Jalan Keluar

\begin{tabular}{llc}
\hline \multicolumn{1}{c}{ Peraturan } & \multicolumn{1}{c}{$\begin{array}{c}\text { Kondisi } \\
\text { Existing }\end{array}$} & $\begin{array}{l}\text { skala } \\
\text { likert }\end{array}$ \\
\hline $\begin{array}{l}\text { Iluminasi jalan ke luar } \\
\text { siap digunakan setiap } \\
\text { saat dalam kondisi } \\
\text { penghuni membutuhkan }\end{array}$ & $\begin{array}{l}\text { Iluminasi jalan } \\
\text { keluar siap } \\
\text { sarana jalan ke luar }\end{array}$ & 5 \\
digunakan & \\
No:26/PRT/M/2008:89) & & \\
\hline
\end{tabular}

Tabel 4. 11 Pencahayaan Darurat

\begin{tabular}{llc}
\hline \multicolumn{1}{c}{ Peraturan } & Kondisi Existing & $\begin{array}{l}\text { skala } \\
\text { likert }\end{array}$ \\
\hline $\begin{array}{l}\text { Peralatan } \\
\text { pencahayaan darurat } \\
\text { sepenuhnya siap }\end{array}$ & $\begin{array}{l}\text { Pencahayaan siap } \\
\text { beroperasi }\end{array}$ \\
beroperasi(Permen & \\
PU & \\
No:26/PRT/M/2008 : & 5 \\
$91)$ & \\
\hline
\end{tabular}

Tabel 4. 12 Penanda Sarana Jalan Keluar

\begin{tabular}{lll}
\hline \multirow{2}{*}{ Peraturan } & Kondisi & skala \\
& Existing & likert \\
\hline
\end{tabular}

Tanda eksit bisa diraba dan terbaca, ditempatkan di setiap pintu eksit (Permen PU No:26/PRT/M/2008 :

Tanda eksit dapat diraba

93)

Tanda eksit diletakkan dengan ukuran, dan warna nyata, mudah dilihat (Permen PU Tanda eksit warnanya nyata

No:26/PRT/M/2008 : 95)

Tanda arah yang menunjukkan arah lintasan, ditempatkan di setiap lokasi, Tanda arah apabila arah lintasan yang mencapai eksit terdekat tidak jelas (Permen PU menunjukkan 5 No:26/PRT/M/2008 : 97)

\section{Sistem Proteksi Pasif}

Hasil pengamatan mengenai sistem proteksi pasif berdasarkan pengamatan di lapangan, disajikan dalam tabel berikut :

Tabel 4. 13 Pasangan Konstruksi Tahan Api

\begin{tabular}{llc}
\hline \multicolumn{1}{c}{ Peraturan } & $\begin{array}{c}\text { Kondisi } \\
\text { Existing }\end{array}$ & $\begin{array}{c}\text { skala } \\
\text { likert }\end{array}$ \\
\hline $\begin{array}{l}\text { Tipe konstruksi tahan terhadap } \\
\text { api (Permen PU }\end{array}$ & $\begin{array}{l}\text { Konstruksi } \\
\text { Tipe A }\end{array}$ & 5 \\
$\begin{array}{l}\text { No:26/PRT/M/200 : 103) } \\
\text { Jenis partisi, penutup atap } \\
\text { tahan }\end{array}$ & $\begin{array}{l}\text { Partisi } \\
\text { terbuat dari }\end{array}$ & \\
terhadap api (Permen PU & $\begin{array}{l}\text { gypsum, dan } \\
\text { No:26/PRT/M/2008 : 103) }\end{array}$ & \\
atap beton & \\
\hline
\end{tabular}


Tabel 4. 14 Pintu dan Jendela Tahan Api

\begin{tabular}{|c|c|c|}
\hline Peraturan & $\begin{array}{l}\text { Kondisi } \\
\text { Existing }\end{array}$ & $\begin{array}{l}\text { skala } \\
\text { likert }\end{array}$ \\
\hline $\begin{array}{l}\text { Jenis pintu dan jendela tahan } \\
\text { terhadap api (Permen PU } \\
\text { No:26/PRT/M/2008 : 104) }\end{array}$ & $\begin{array}{l}\text { Pintu dan } \\
\text { jendela kaca }\end{array}$ & 5 \\
\hline \multicolumn{3}{|c|}{ Tabel 4. 15 Bahan Pelapis Interior } \\
\hline Peraturan & $\begin{array}{l}\text { Kondisi } \\
\text { Existing }\end{array}$ & $\begin{array}{l}\text { skala } \\
\text { likert }\end{array}$ \\
\hline $\begin{array}{l}\text { Bahan pelapis interior tahan } \\
\text { terhadap api (Permen PU } \\
\text { No:26/PRT/M/2008 : 104) }\end{array}$ & $\begin{array}{l}\text { Bahan } \\
\text { pelapis } \\
\text { interios } \\
\text { gypsum }\end{array}$ & 5 \\
\hline
\end{tabular}

Tabel 4. 16 Penghalang Api

\begin{tabular}{llc}
\hline \multicolumn{1}{c}{ Peraturan } & $\begin{array}{c}\text { Kondisi } \\
\text { Existing }\end{array}$ & $\begin{array}{l}\text { skala } \\
\text { likert }\end{array}$ \\
\hline $\begin{array}{l}\text { Terdapat sistem peralatan } \\
\text { penyetop api seperti kabel }- \\
\text { kabel, rak kabel, pemipaan, } \\
\text { tabung, ven asap dan ven } \\
\text { pembuangan (Permen PU }\end{array}$ & $\begin{array}{l}\text { perdapat } \\
\text { penyetop api }\end{array}$ & 5 \\
$\begin{array}{l}\text { No:26/PRT/M/2008 : 109) } \\
\text { Terdapat saluran udara, seperti } \\
\text { ventilasi untuk pengkodisian }\end{array}$ & verdapat & \\
$\begin{array}{l}\text { udara (Permen PU } \\
\text { No:26/PRT/M/2008 : 115) }\end{array}$ & & 5 \\
\hline
\end{tabular}

Tabel 4. 17 Partisi Penghalang Api

\begin{tabular}{|c|c|c|}
\hline Peraturan & $\begin{array}{c}\text { Kondisi } \\
\text { Existing } \\
\end{array}$ & $\begin{array}{l}\text { skala } \\
\text { likert }\end{array}$ \\
\hline $\begin{array}{l}\text { Partisi dipasang membentang } \\
\text { dari lantai hingga di bagian } \\
\text { bawah atap atau geladak atap } \\
\text { diatas, melewati ruang - ruang } \\
\text { tersembunyi seperti di atas } \\
\text { langit - langit gantung, dan } \\
\text { melewati ruang - ruang antara } \\
\text { struktur dan mekanikal (Permen } \\
\text { PU No:26/PRT/M/2008 : 116) } \\
\text { Pintu tidak memiliki kisi - kisi } \\
\text { (Permen PU No:26/PRT/M/ } \\
\text { 2008 : 117) } \\
\text { Pintu menutup sendiri atau } \\
\text { menutup secara otomatis } \\
\text { (Permen } \\
\text { PU No:26/PRT/M/2008 : 117) }\end{array}$ & $\begin{array}{l}\text { Partisi } \\
\text { dipasang } \\
\text { dari lantai } \\
\text { hingga atas } \\
\text { palfon } \\
\\
\\
\text { Pintu tidak } \\
\text { memiliki } \\
\text { kisi-kisi } \\
\text { Pintu } \\
\text { menutup } \\
\text { secara } \\
\text { otomatis }\end{array}$ & 5 \\
\hline \multicolumn{3}{|c|}{ Tabel 4. 18 Penghalang Asap } \\
\hline Peraturan & $\begin{array}{c}\text { Kondisi } \\
\text { Existing } \\
\end{array}$ & $\begin{array}{l}\text { skala } \\
\text { likert }\end{array}$ \\
\hline Pintu pada penghalang asap $\mathrm{F}$ & Pintu & 5 \\
\hline
\end{tabular}

\begin{tabular}{|c|c|c|}
\hline \begin{tabular}{l}
\multicolumn{1}{c}{ dari } \\
jenis pintu yang bisa \\
menutup sendiri atau \\
menutup sendiri secara \\
otomatis (Permen PU \\
No:26/PRT/M/2008: 119)
\end{tabular} & $\begin{array}{l}\text { penghalang } \\
\text { asap } \\
\text { menutup } \\
\text { secara } \\
\text { otomatis }\end{array}$ & \\
\hline \multicolumn{3}{|l|}{ Tabel 4. 19 Atrium } \\
\hline Peraturan & $\begin{array}{l}\text { Kondisi } \\
\text { Existing }\end{array}$ & $\begin{array}{l}\text { skala } \\
\text { likert }\end{array}$ \\
\hline $\begin{array}{l}\text { Bangunan gedung diproteksi } \\
\text { keseluruhannya dengan sistem } \\
\text { prinkler otomatis (Permen PU } \\
\text { No:26/PRT/M/2008: } 123 \text { ) }\end{array}$ & $\begin{array}{l}\text { Terdapat } \\
\text { spinkler } \\
\text { otomatis }\end{array}$ & 5 \\
\hline
\end{tabular}

\section{B. Penerapan Sarana Penyelamatan dan Sistem Proteksi Pasif}

Penerapan sarana penyelamatan dan sistem proteksi pasif diperoleh dari penerapan peraturan yang dinilai dengan menggunakan skala likert. Skala likert terdiri dari 5 skala.

\section{Sarana Penyelamatan}

Skala likert dihitung menggunakan rumus 2.1 dengan hasil yang disajikan dalam tabel sebagai berikut :

Tabel 4. 20 Analisis Peraturan Sarana Penyelamatan dalam skala likert

\begin{tabular}{clc}
\hline No. & \multicolumn{1}{c}{ Tinjauan } & $\begin{array}{c}\text { Skala } \\
\text { likert }\end{array}$ \\
\hline 1 & Eksit & 5 \\
2 & Keandalan Jalan Keluar & 5 \\
3 & Pintu & 5 \\
4 & Ruang Terlindung dan Proteksi & 5 \\
& tangga & 5 \\
5 & Jalan Terusan eksit & 5 \\
6 & Jumlah Sarana Jalan Keluar & 5 \\
7 & Susunan jalan Kaluar & 5 \\
8 & Eksit Pelepasan & 5 \\
9 & Iluminasi sarana Jalan Keluar & 5 \\
10 & Pencahayaan darurat & 5 \\
11 & Penandaan Sarana Jalan Keluar & 5 \\
Jumlah Rarata-rata & sarana \\
penyelamatan & $\mathbf{5}$ \\
\hline
\end{tabular}

Penerapan peraturan sarana penyelamatan seperti pada tabel tersebut di atas menghasilkan jumlah rata - rata sebesar 5 dalam skala likert. Hal ini menunjukkan sarana penyelamatan di Gedung Menara Bosowa telah sesuai dengan peraturan. 
2. Sistem Proteksi Pasif

Skala likert dihitung menggunakan rumus 2.1. dengan hasil yang disajikan dalam tabel sebagai berikut :

Tabel 4. 21 Analisis Peraturan Sistem Proteksi Pasif dalam skala likert

\begin{tabular}{llc}
\hline No. & \multicolumn{1}{c}{ Tinjauan } & Skala likert \\
\hline 1 & Pasangan Konstruksi Tahan Api & 5 \\
2 & Pintu dan Jendala Tahan Api & 5 \\
3 & Bahan Pelapis interior & 5 \\
4 & Penghalang Api & 5 \\
5 & Partisi Penghalang Api & 5 \\
6 & Penghalang Asap & 5 \\
7 & Atrium & 5 \\
Jumlah Rata-rata sarana penyelamatan & $\mathbf{5}$ \\
\hline
\end{tabular}

Penerapan peraturan sistem proteksi pasif seperti pada tabel tersebut di atas menghasilkan jumlah rata - rata sebesar 5 dalam skala likert. Hal ini menunjukkan sistem proteksi pasif di Gedung Menara Bosowa sangat sesuai dengan peraturan.

\section{Analisis Deskriptif - Kuantitatif}

Analisis deskriptif ini mengetahui nilai keandalan sistem keselamatan bangunan terhadap bahaya kebakaran melalui pengamatan langsung. Dalam menilai keandalan suatu bangunan ditentukan oleh peraturan Pd $-\mathrm{T}-11-2005-\mathrm{C}$ tentang Pemeriksaan Keselamatan Kebakaran Bangunan Gedung yang didalamnya memiliki beberapa aspek, antara lain, kelengkapan tapak, sarana penyelamatan, sarana proteksi aktif, dan sarana proteksi pasif.

\section{a. Kelengkapan Tapak}

Komponen kelengkapan tapak terdiri atas 4 subkomponen, yaitu sumber air, jalan lingkungan, jarak antar bangunan, dan hidran halaman. Untuk mendapatkan nilai kondisi komponen kelengkapan tapak Gedung Menara Bosowa, diperlukan nilai kondisi dari keempat subkomponen tersebut. Pemaparan nilai konidisi dari empat subkomponen tersebut akan diuraikan dalam bagian berikut.

\section{1) Sumber Air}

Berdasarkan hasil wawancara dengan informan, jika kapasitas air di Gedung Menara Bosowa telah memenuhi syarat minimal terhadap fungsi bangunan. "...sumber air telah mencukupi pemakaian seluruh bangunan gedung karena sumber airnya sudah Dipersiapkan untuk 1-3 jam dengan kapasitas lebih dari 300 m...” (ik)

Tabel 4. 22 Hasil Pemenuhan Kriteria Penilaian Sumber Air

\begin{tabular}{llc}
\hline \multicolumn{1}{c}{ Kriteria Penilaian } & Kondisi Aktual & Nilai \\
\hline Tersedia dengan & Sumber air & $\mathrm{B}$ \\
kapasitas yang & berasal dari air & $(100)$ \\
Memenuhi & tanah dan PDAM & \\
Persyaratan minimal & terdapat ground \\
terhadap fungsi & tank dengan & \\
bangunan & kapasitas \pm 300 & \\
& $\mathrm{~m}^{3}$ \\
\hline
\end{tabular}

2) Jalan Lingkungan

Subkomponen jalan lingkungan mensyaratakan bahwa jalan lingkungan harus tersedia dengan lebar minimal $6 \mathrm{~m}$, diberi pengerasan, dan lebar jalan masuk minimal $4 \mathrm{~m}$. Kondisi aktual jalan lingkungan Gedung Menara Bosowa telah memenuhi tiga kriteria yang telah disebutkan. Hasil pengukuran langsung menunjukkan jalan lingkungan Gedung Menara Bosowa memiliki lebar di atas $6 \mathrm{~m}$, jalan lingkungan telah diberi pengerasan aspal, serta lebar jalan masuk di atas 4 meter sehingga memungkinkan mobil pemadam kebakaran untuk masuk ke area sekitar Gedung Menara Bosowa. Pemenuhan kriteria jalan lingkungan dapat dilihat dalam tabel berikut.

Tabel 4. 23 Hasil Pemenuhan Kriteria Penilaian Jalan Lingkungan

\begin{tabular}{llc}
\hline \multicolumn{1}{c}{$\begin{array}{c}\text { Kriteria } \\
\text { Penialaian }\end{array}$} & \multicolumn{1}{c}{ Kondisi Aktual } & Nilai \\
\hline Tersedia & Tersedia dengan & $\mathrm{B}$ \\
dengan lebar & lebar 6m; diberi & $(100)$ \\
6m; diberi & pengerasan; lebar & \\
pengerasan; & jalan masuk 4 m & \\
lebar jalan & & \\
masuk 4 m & \\
\hline
\end{tabular}

\section{3) Jarak Antar Bangunan}

Penilaian subkomponen jarak antar bangunan dilakukan dengan observasi langsung yaitu pengukuran dengan alat bantu meteran dan telaah dokumen. Posisi Gedung Menara Bosowa dengan bangunan terdekat akan dihitung jarak antar keduanya sehingga 
menghasilkan informasi terpenuhi atau tidaknya subkomponen jarak antar bangunan.

Bangunan Gedung Menara Bosowa berada dalam kisaran tinggi $105.2 \mathrm{~m}$ hingga jarak antar bangunan yang dipersyaratkan adalah lebih $8 \mathrm{~m}$. Pemenuhan kriteria jalan lingkungan dapat dilihat dalam tabel berikut.

Tabel 4. 24 Hasil Pemenuhan Kriteria Penilaian Jarak Antar Bangunan

\begin{tabular}{llc}
\hline \multicolumn{1}{c}{ Kriteria Penilaian } & \multicolumn{1}{c}{$\begin{array}{c}\text { Kondisi } \\
\text { Aktual }\end{array}$} & Nilai \\
\hline Jika tinggi bangunan & Jarak dengan & $\mathrm{B}$ \\
di atas 40m, maka & bangunan & $(100)$ \\
jarak antar & terdekat hanya & \\
bangunannya adalah & sekitar $12,45 \mathrm{~m}$ & \\
lebih dari $8 \mathrm{~m}$ & & \\
\hline
\end{tabular}

\section{4) Hidran Halaman}

Hidran halaman yang dimiliki oleh Gedung Menara Bosowa sudah tersedia di halaman dan mudah dijangkau oleh petugas pemadam. Selain itu, hidran halaman tersebut juga pernah diujicoba oleh petugas pemadam sehingga dapat disimpulkan jika hidran halaman tersebut berfungsi sempurna dan lengkap. Dalam ujicoba tersebut diketahui pula tekanan airnya berkisar antara 3,5 - 4 bar sementara suplai air berkisar antara 38 - 40 liter/detik. Pememuhan kriteria hidran halaman dapat dilihat dalam tabel berikut.

Tabel 4. 25 Hasil Pemenuhan Kriteria Penilaian Hidran Halaman

\begin{tabular}{llc}
\hline \multicolumn{1}{c}{$\begin{array}{c}\text { Kriteria } \\
\text { Penilaian }\end{array}$} & \multicolumn{1}{c}{$\begin{array}{c}\text { Kondisi } \\
\text { Aktual }\end{array}$} & Nilai \\
\hline Hidran halaman & Tersedia di & B \\
tersedia di halaman & halaman; & $(100)$ \\
hidran halaman & mudah & \\
harus mudah & dijangkau; & \\
dijangkau; hidran & berfungsi & \\
halaman harus & sempurna dan & \\
berfungsi sempurna & lengkap; suplai & \\
dan lengkap; & air 38 - 40 & \\
suplaiair hidran & liter/detik & \\
halaman adalah 38 & tekanan 3,5-4 & \\
liter/detik; tekanan & bar; \\
air hidran halaman & \\
adalah 3,5 bar & & \\
\hline
\end{tabular}

\section{b. Sistem Proteksi Aktif}

Komponen sistem proteksi aktif yang diperiksa di Gedung Menara Bosowa terdiri atas 13 subkomponen yang meliputi deteksi dan alarm, siames connection, alat pemadam api ringan (apar), hidran gedung, springkler, sistem pemadam luapan, pengendali asap, deteksi asap, pembuangan asap, lift kebakaran, cahaya darurat, listrik darurat, dan ruang pengendali operasi. Penilaian terhadap ketigabelas subkomponen tersebut akan dijelaskan pada bagian berikut ini.

\section{1) Deteksi dan alarm}

Kebakaran merupakan peristiwa yang terjadi saat suatu bahan mencapai temperatur kritis dan secara kimia dengan oksigen yang menghasilkan panas, nyala api, cahaya, uap air, asap, karbon monoksida, atau produk dan efek lainnya. Detektor melakukan alat yang dirancang untuk mendeteksi adanya kebakaran dan mengawali suatu tindakan (SNI 033985-2000).

Pemenuhan kriteria-kriteria subkomponen deteksi dan alarm Gedung Menara Bosowa dapat dilihat dalam tabel berikut.

Tabel 4. 26 Hasil Pemenuhan Kriteria Penilaian Deteksi dan Alarm

\begin{tabular}{llc}
\hline \multicolumn{1}{c}{ Kriteria penilaian } & \multicolumn{1}{c}{ Kondisi aktual } & Nilai \\
\hline $\begin{array}{l}\text { Detektor harus } \\
\text { dilindungi dari bahaya } \\
\text { gangguan mekanis }\end{array}$ & $\begin{array}{l}\text { Detektor telah } \\
\text { dilindungi dari } \\
\text { bahaya gangguan } \\
\text { mekanik }\end{array}$ & \\
Detektor harus & $\begin{array}{l}\text { Detektor sudah } \\
\text { dipasang pada seluruh } \\
\text { terpasang di } \\
\text { daerah ruangan }\end{array}$ & $\begin{array}{l}\text { seluruh area } \\
\text { ruangan }\end{array}$ \\
Setiap detektor yang & Detektor yang & \\
terpasang harus dapat & terpasang telah & \\
dijangkau untuk & dapat dijangkau & \\
pemeliharaan dan & untuk \\
pengujian secara & pemeliharaan dan & \\
periodik & pengujian & \\
Tersedianya detector & Detektor panas & \\
panas & sudah tersedia & \\
Terpasangnya alat & Alarm manual & \\
manual pemicu alarm & sudah tersedia & \\
Jarak detektor tidak & Jarak detektor - \\
boleh lebih dari $30 \mathrm{~m}$ & alarm manual tidak & \\
dari titik alarm manual & lebih dari 30 meter & \\
\hline
\end{tabular}


2) Siamese connection

Siamese connection adalah sebuah bagian yang sering ditemukan dalam suatu sistem pipa tegak. Fungsi dari Siamese Connection ini adalah untuk memberikan tambahan suplai air, tetapi tidak menyediakan suplai air untuk keseluruhan sistem springkler (Minnesota fire state marshal, 2006).

Pemenuhan kriteria subkomponen siamese connection Gedung Menara Bosowa dijelaskan dalam tabel berikut.

Tabel 4. 27 Hasil pemenuhan kriteria siamese connection

\begin{tabular}{llc}
\hline \multicolumn{1}{c}{ Kriteria penilaian } & \multicolumn{1}{c}{ Kondisi aktual } & Nilai \\
Siamese connection & Sudah tersedia dan & $\mathrm{B}$ \\
tersedia dan ditempatkan & ditempatkan pada lokasi & $(100)$ \\
pada lokasi yang mudah & yang mudah dijangkau & \\
dijangkau mobil pemadam & mobil pemadam & \\
siamese connection diberi & dilengkapi petunjuk & \\
tanda petunjuk hingga & \\
mudah dikenali & & \\
\hline
\end{tabular}

Hasil pengamatan langsung menunjukkan siamese connection sudah ditempatkan di lokasi yang mudah dijangkau mobil pemadam dan telah diberi penanda atau tanda penunjuk agar siamese connection tersebut mudah dikenali.

3) Alat Pemadam Api Ringan (APAR)

Pemenuhan kriteria subkomponen apar di

Gedung Menara Bosowa dapat dilihat melalui tabel berikut.

Tabel 4. 28 Hasil pemenuhan kriteria APAR

\begin{tabular}{llc}
\hline \multicolumn{1}{c}{ Kriteria penilaian } & \multicolumn{1}{c}{ Kondisi aktual } & Nilai \\
\hline $\begin{array}{l}\text { Jumlah apar sesuai } \\
\text { dengan luas bangunan }\end{array}$ & $\begin{array}{l}\text { Jumlah sudah sesuai dengan } \\
\text { luas bangunan }\end{array}$ & B \\
Jarak antar apar & Jarak antar apar tidak lebih & \\
maksimal $25 \mathrm{~m}$ & dari $25 \mathrm{~m}$ & \\
$\begin{array}{l}\text { Penempatan apar mudah } \\
\text { dilihat termasuk instruksi }\end{array}$ & Apar mudah dilihat, serta & \\
pengoperasiannya dan & Pengoperasat instruksi & \\
tanda identifikasinya & identifikasinya & \\
$\begin{array}{l}\text { Apar tidak boleh } \\
\text { terhalang oleh peralatan } \\
\text { atau material- material }\end{array}$ & Apar tidak terhalang \\
$\begin{array}{l}\text { Penempatan apar } \\
\text { minimum } 15 \mathrm{~cm} \text { dari }\end{array}$ & Jarak apar dengan \\
permukaan lantai & permukaan lantai $50 \mathrm{~cm}$ & \\
\hline
\end{tabular}

Dari dokumen re-layout Gedung Menara Bosowa, luas keseluruhan bangunan Gedung Menara Bosowa adalah sekitar 31584,60 m2 (339976,64 ft2). Maka berdasarkan NFPA 10 kebutuhan APAR dapat dihitung sebagai berikut;

Kebutuhan APAR: $\frac{339976,64 \mathrm{ft} 2}{6000 \mathrm{ft2}}=56$ APAR
4) Hidran Gedung

Pemenuhan kriteria subkomponen hidran gedung dapat dilihat melalui tabel berikut.

Tabel 4. 29 Hasil pemenuhan kriteria hidran gedung.

\begin{tabular}{|c|c|c|}
\hline Kriteria & $\begin{array}{l}\text { Kondisi } \\
\text { aktual }\end{array}$ & Nilai \\
\hline Tersedia sambungan selang & Sudah & B \\
\hline diameter $35 \mathrm{~mm}$ dalam & tersedia & $(100)$ \\
\hline kondisi baik, panjang selang & lengkap & \\
\hline minimal $30 \mathrm{~m}$, dan tersedia & dengan & \\
\hline kotak untuk menyimpan & kondisi baik & \\
\hline $\begin{array}{l}\text { Pasokan air cukup tersedia } \\
\text { sekurang-kurangnya untuk } \\
45 \text { menit }\end{array}$ & $\begin{array}{l}\text { Pasokan air } \\
\text { telah cukup }\end{array}$ & \\
\hline 'Bangunan kelas 4, luas 1000 & Lt. 19-G & \\
\hline m2/buah (kompartemen & terdapat 2 & \\
\hline tanpa partisi), 2 buah/1000 & buah dan Lt & \\
\hline m2 (kompartemen dengan & $23-20$ & \\
\hline partisi) bangunan kelas 5 , & terdapat 1 & \\
\hline luas $800 \mathrm{~m} 2 /$ buah tanpa & buat setiap & \\
\hline $\begin{array}{l}\text { partisi, dan } 2 \text { buah/ } 800 \mathrm{~m} 2 \\
\text { dengan partisi }\end{array}$ & lantai & \\
\hline
\end{tabular}

\section{5) Sprinkler}

Sprinkler dalam SNI 03-3989-2000 tentang tata cara perencanaan dan pemasangan sistem sprinkler otomatik untuk pencegahan kebakaran pada bagunan gedung mendefinisikan sprinkler sebagai suatau instalasi pemadaman kebakaran yang dipasang secara tetap/permanen di dalam bangunan yang dapat memadamkan kebakaran secara otomatis dengan menyemprotkan air di tempat mula terjadinya kebakaran. Berdasarkan klasifikasi hunian bahaya kebakaran, sni 03-3989-2000 membagi sistem sprinkler menjadi tiga, yaitu sistem bahaya kebakaran ringan, sistem bahaya kebakaran sedang, dan sistem bahaya kebakaran berat. 
Tabel 4. 30 Hasil pemenuhan kriteria Sprinkler

\begin{tabular}{|c|c|c|}
\hline Kriteria penilaian & Kondisi aktual & Nilai \\
\hline $\begin{array}{l}\text { Jumlah, perletakan } \\
\text { dan jenis sesuai } \\
\text { dengan persyaratan }\end{array}$ & $\begin{array}{l}\text { Sprinkler sesuai } \\
\text { dengan standar }\end{array}$ & $\begin{array}{c}\mathrm{B} \\
(100)\end{array}$ \\
\hline $\begin{array}{l}\text { Tekanan catu air } \\
\text { sprinkler pada titik } \\
\text { terjauh }(0,5-2,0) \\
\mathrm{kg} / \mathrm{cm}^{2}\end{array}$ & $\begin{array}{l}\text { Tekanan catu air } \\
\text { sprinkler telah } \\
\text { mencapai titik } \\
\text { terjauh }(0,5-2,0) \\
\mathrm{kg} / \mathrm{cm}^{2}\end{array}$ & \\
\hline $\begin{array}{l}\text { Debit sumber catu } \\
\text { air minimal (40-200) } \\
\text { liter/menit per } \\
\text { kepala sprinkler }\end{array}$ & $\begin{array}{l}\text { Debit sumber catu } \\
\text { air telah mencapai } \\
(40-200) \\
\text { liter/menit per } \\
\text { kepala sprinkler }\end{array}$ & \\
\hline $\begin{array}{l}\text { Jarak kepala } \\
\text { sprinkler kedinding } \\
<1 / 2 \text { jarak antar } \\
\text { kepala sprinkler }\end{array}$ & $\begin{array}{l}\text { Jarak kepala } \\
\text { sprinkler } 4 \text { meter, } \\
\text { ke dinding } 2 \text { meter }\end{array}$ & \\
\hline $\begin{array}{l}\text { Jarak maks sprinkler } \\
\text { : Kebakaran ringan } \\
\text { dan sedang }=4,6 \mathrm{~m} \\
\text { Kebakaran berat }= \\
3,7 \mathrm{~m}\end{array}$ & $\begin{array}{l}\text { Jarak kepala } \\
\text { sprinkler } 4 \text { meter }\end{array}$ & \\
\hline $\begin{array}{l}\text { Dalam ruang } \\
\text { tersembunyi, jarak } \\
\text { langit-langit dan atap } \\
\text { lebih } 80 \mathrm{~cm}, \\
\text { dipasang jenis } \\
\text { kepala sprinkler } \\
\text { dengan pancaran } \\
\text { keatas }\end{array}$ & $\begin{array}{l}\text { Tidak terdapat } \\
\text { ruang yang } \\
\text { tersembunyi }\end{array}$ & \\
\hline
\end{tabular}

\section{6) Sistem Pemadam Luapan}

Sistem pemadam luapan harus tersedia untuk ruangan atau bangunan yang memerlukan sistem khusus seperti ruang komunikasi, ruang komputer, ruang magnetik, ruang elektronik, dan lainnya. Sistem pemadam khusus ini dapat berupa gas, busa, dan bubuk kering (Yervi Hesna dkk, 2009)

“...Gedung beroperasi selama jam kerja sehingga aktifitas SDM pun akan berlangsung 24 jam selama 5 hari. Selain itu pekerja dan satpam sudah diberi pelatihan penanganan kebakaran. Serta, sudah terdapat garis komando untuk di luar jam kerja normal sehingga gedung bisa terus terpantau...” (IK)

\section{7) Pengendali Asap}

Pengendalian asap harus disediakan untuk bagunan kelas 2 sampai kelas 9. Gedung Menara Bosowa termaksud dalam bangunan kelas 5 :
Bangunan kantor. Sistem pengendalian asap dirancang dengan tujuan untuk menghalangi aliran asap ke dalam sarana jalan keluar, jalam terusan keluar, daerah tempat berlindung, atau daerah lain yang serupa.

Tabel 4. 31 Hasil pemenuhan kriteria pengendali asap

\begin{tabular}{llc}
\hline \multicolumn{1}{c}{ Kriteria penilaian } & Kondisi aktual & Nilai \\
\hline $\begin{array}{l}\text { Fan pembuangan asap akan } \\
\text { berputar berurutan setelah } \\
\text { aktifnya detektor asap yang }\end{array}$ & & \multicolumn{1}{c}{ B } \\
ditempatkan dalam zona & \\
sesuai dengan reservoir & \\
asap yang dilayani, dan & \\
Detektor asap harus dalam & Detektor asap \\
keadaan bersih dan tidak & dalam keadaan \\
terhalang oleh benda lain & bersih dan tidak \\
disekitarnya & terhalang \\
Di dalam kompartemen & Tidak menyatu \\
bertingkat banyak, sistem & dengan \\
pengolahan udara & pembuangan \\
beroperasi dengan & asap \\
menggunakan seluruh & \\
udara segar melalui ruang & \\
kosong bangunan tidak & \\
menjadi satu dengan & \\
cerobong pembuangan & \\
asap & \\
Tersedia panel kontrol & Tidak terdapat \\
manual dan indikator & panel kontrol \\
kebakaran serta buku & manual dan \\
petunjuk pengoperasian & indikator \\
bagi petugas jaga & kebakaran serta \\
& buku petunjuk \\
& pengoprasian \\
& bagi petugas \\
\hline
\end{tabular}

8) Deteksi Asap

Penilaian terhadap deteksi asap yang terdapat di Gedung Menara Bosowa dapat dilihat dalam tabel berikut. 
Tabel 4. 32 Hasil pemenuhan kriteria deteksi asap

\begin{tabular}{llc}
\hline \multicolumn{1}{c}{ Kriteria penilaian } & Kondisi aktual & Nilai \\
\hline Sistem deteksi asap & Sistem deteksi & B \\
memenuhi SN 03-3989 & mengaktifkan & $(100)$ \\
mengaktifkan sistem & peringatan bagi \\
peringatan penghuni & seluruh & \\
bangunan & penghuni \\
Pada ruang dapur area lain & Detektor panas \\
yang sering mengakibatkan & telah terpasang \\
terjadinya alarm palsu & \\
dipasang alarm panas, & \\
terkecuali telah dipasang & \\
sprinkler & \\
$\begin{array}{l}\text { Detektor asap yang } \\
\text { terpasang dapat }\end{array}$ & Detektor \\
mengaktifkan sistem & mengaktifkan \\
pengolahan udara secara & pengolahan \\
otomatis, sistem & udara secara \\
pembuangan asap, ventilasi & otomatis \\
asap dan panas & \\
Jarak antara detektor $<$ & Jarak antar \\
20m dan < 10m dari & detektor $<20 \mathrm{~m}$ \\
dinding pemisah atau tirai & dan $<10$ m \\
asap & dari dinding \\
& pemisah Atau \\
& tirai asap \\
\hline
\end{tabular}

\section{9) Lift Kebakaran}

Pedoman pemeriksaan keselamatan kebakaran gedung Pd-T- 11-2005-C Departemen PU yang digunakan dalam tulisan ini memberikan kriteria bahwa lift kebakaran sekurang-kurangnya harus dipasang pada bangunan dengan ketinggian efektif 25 meter. Berdasarkan dokumen perencanaan relayout gedung Menara Bosowa Jalan Jend. Sudirman No.7 Makassar, bangunan Gedung Menara Bosowa memiliki tinggi sekitar 105.2 meter dengan 23 lantai sehingga masuk dalam kriteria subkomponen lift kebakaran.

Berdasarkan kondisi aktual dan hasil wawancara dengan informan, berdasarkan pengamatan dilapangan menujukan tidak adanya liff kebakaran diGedung Menara Bosowa.

\footnotetext{
“... karena adanya lift service yang difungsikan..." (ik)
}

10) Cahaya Darurat dan Petunjuk Arah

Penilaian kondisi aktual dari subkomponen cahaya darurat dan petunjuk arah dilakukan dengan pengamatan langsung. Hasil penilaian subkomponen cahaya darurat dan petunjuk arah dapat dilihat melalui tabel berikut.
Tabel 4. 33 Hasil Pemenuhan Kriteria Cahaya Darurat dan Petunjuk Arah

\begin{tabular}{llc}
\hline \multicolumn{1}{c}{ Kriteria Penilaian } & Kondisi Aktual & Nilai \\
\hline Sistem pencahayaan & Sudah tersedia & $\mathrm{B}$ \\
darurat harus dipasang di & $\begin{array}{l}\text { pencahayaan } \\
\text { setiap tangga yang }\end{array}$ & $(100)$ \\
dilindungi terhadap & & \\
kebakaran, di setiap lantai & & \\
dengan luas $>300 \mathrm{~m}^{2}$, di & & \\
setiap jalan terusan, & & \\
koridor. & &
\end{tabular}

Desain sistem

Sistem

pencahayaan darurat

beroperasi otomatis,

pencahayaan

memberikan pencahayaan beroperasi

yang cukup, dan harus otomatis dan

memenuhi standar yang memberikan

berlaku.

Tanda exit terlihat dan terpasang berdekatan

dengan pintu yang

memberikan jalan keluar

langsung, pintu dari suatu

tangga, exit horizontal

dan pintu yang melayani

exit.

Bila exit tidak terlihat secara langsung dengan

jelas oleh penghuni harus dipasang tanda petunjuk dengan tanda panah dan penunjuk arah.

Setiap tanda exit harus Tanda exit jelas dan pasti, diberi sudah diberi pencahayaan yang cukup, pencahayaan dipasang sedemkian rupa cukup, terlihat sehingga tidak terjadi jelas dan pasti. gangguan listrik, tanda petunjuk arah keluar harus memenuhi standar yang berlaku. pencahayaan yang cukup.

Tanda exit terlihat dan terpasang dengan pintu yang melayani exit.

Exit yang terpasang sudah disertai dengan penunjuk arah. 


\section{Listrik Darurat}

Hasil penilaian subkomponen listrik darurat dapat dilihat melalui tabel berikut.

Tabel 4. 34 Hasil Pemenuhan Kriteria Listrik Darurat

\begin{tabular}{|c|c|c|}
\hline Kriteria Penilaian & Kondisi Aktual & Nilai \\
\hline $\begin{array}{l}\text { Daya yang disuplai } \\
\text { sekurang-kurangnya dari } \\
\text { dua sumber yaitu PLN, } \\
\text { atau sumber daya } \\
\text { darurat (batere, } \\
\text { generator, dll). }\end{array}$ & $\begin{array}{l}\text { Terdapat dua sumber } \\
\text { listrik: PLN dan } \\
\text { Genset }\end{array}$ & $\begin{array}{c}\text { B } \\
(90)\end{array}$ \\
\hline $\begin{array}{l}\text { Semua intalasi kabel } \\
\text { yang melayani sumber } \\
\text { daya listrik harus tahan } \\
\text { api selama } 60 \text { menit, } \\
\text { catu daya dari sumber } \\
\text { daya ke motor harus } \\
\text { memenuhi ketentuan }\end{array}$ & $\begin{array}{l}\text { Instalasi kabel telah } \\
\text { tidak dapat menahan } \\
\text { api, kecuali instalasi } \\
\text { darurat }\end{array}$ & \\
\hline $\begin{array}{l}\text { Memenuhi cara } \\
\text { pemasangan kabel yang } \\
\text { termuat dalam PUIL. }\end{array}$ & $\begin{array}{l}\text { Memenuhi cara } \\
\text { pemasangan sesuai } \\
\text { dengan PUIL. }\end{array}$ & \\
\hline
\end{tabular}

Sumber listrik untuk kebutuhan daya di Gedung Menara Bosowa Makassar telah sesuai kriteria karena suplai daya berasal lebih dari satu sumber. Hal ini dipertegas dari informasi informan .

“...sumber listrik berasal dari PLN dan Genset ..." (ik)

\section{Ruang Pengendali Operasi}

Hasil penilaian terhadap subkomponen ruang pengendali operasi dapat dilihat dalam tabel berikut :

Tabel 4. 35 Hasil Pemenuhan Kriteria Ruang Pengendali Operasi

\begin{tabular}{llc}
\hline \multicolumn{1}{c}{ Kriteria Penilaian } & \multicolumn{1}{c}{ Kondisi Aktual } & Nilai \\
\hline Tersedia dengan & Tersedia dengan & $\mathrm{B}$ \\
peralatan yang lengkap & terdapatnya CCTV & $(100)$ \\
dan dapat memonitor & yang diletakkan di & \\
$\begin{array}{l}\text { bahaya kebakaran yang } \\
\text { akan terjadi. }\end{array}$ & berbagai titik. & \\
\hline
\end{tabular}

Hasil pengamatan di Gedung Menara Bosowa sudah memasang CCTV di berbagai titik dengan pusat kendali di ruang pengendali operasi yang berada dibasement. Kegiatan dalam gedung secara umum, keberadaan CCTV juga cukup membantu memonitor bahaya kebakaran.

\section{Sistem Proteksi Pasif}

Komponen sistem proteksi pasif yang diperiksa di Gedung Menara Bosowa Makassar terdiri atas 3 subkomponen yang meliputi ketahan api struktur bangunan, kompartemenisasi ruangan, dan perlindungan bukaan. Penilaian terhadap ketiga subkomponen tersebut akan dijelaskan pada bagian berikut ini.

1) Ketahanan Api Struktur Bangunan

Penilaian subkomponen ketahanan struktur api bangunan dilakukan dengan membandingkan kondisi aktual gedung bangunan dengan kriteria penilaian ketahanan api struktur bangunan. Hasil penilaian subkomponen ketahanan api strukutur bangunan Gedung Menara Bosowa Makassar dapat dilihat melaui tabel berikut.

Tabel 4. 36 Hasil Pemenuhan Ketahanan Api Struktur Bangunan

\begin{tabular}{llc}
\hline \multicolumn{1}{c}{ Kriteria Penilaian } & $\begin{array}{c}\text { Kondisi } \\
\text { Aktual }\end{array}$ & Nilai \\
\hline Ketahanan api komponen Ketahanan api & $\mathrm{B}$ \\
struktur bangunan sesuai & struktur & $(100)$ \\
dengan yang & bangunan & \\
dipersyaratkan (Tipe A, & sudah sesuai. & \\
B, C) yang sesuai dengan & \\
fungsi/klasifikasi & \\
bangunannya. & \\
\hline
\end{tabular}

Gedung Menara Bosowa Makassar termasuk dalam struktur bangunan tipe A dan konstruksinya sudah memenuhi persyaratan ketahanan api untuk bangunan tipe A yaitu konstruksi dari bahan beton. Kepmen PU Nomor 11 Tahun 2000 menyebutkan jika beton merupakan salah satu bahan konstruksi yang tahan api. Hal ini kemudian diperkuat dengan informasi dari informan.

2) Kompartemenisasi Ruangan

Penilaian sub komponen kompartemenisasi dapat dilihat pada tabel berikut ini : 
Tabel 4. 37 Hasil Pemenuhan Kriteria Kompartemenisasi Ruangan

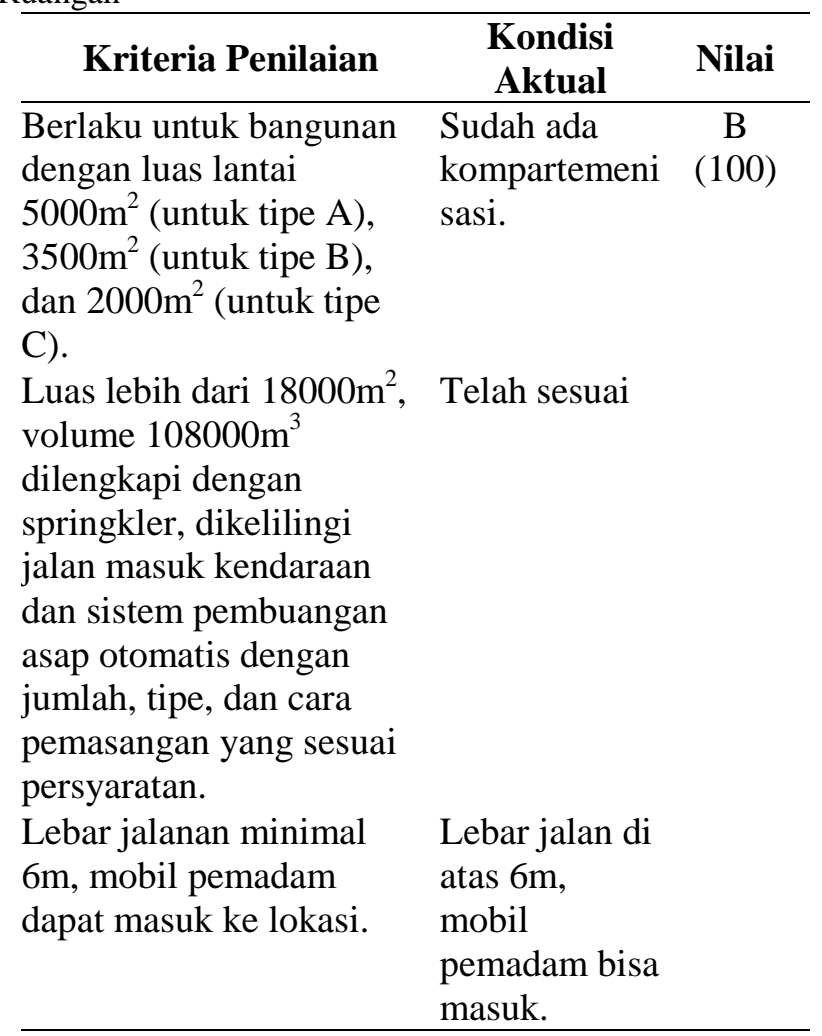

Berdasarkan pengamatan dan informasi dari informan gedung Gedung Menara Bosowa Makassar telah memiliki kompartemenisasi.

\section{3) Perlindungan Bukaan}

Penilaian sub komponen perlindungan bukaan Gedung Menara Bosowa Makassar dapat dilihat pada tabel berikut ini :
Tabel 4. 38 Hasil Pemenuhan Kriteria Perlindungan Bukaan

\begin{tabular}{llc}
\hline \multicolumn{1}{c}{ Kriteria Penilaian } & $\begin{array}{l}\text { Kondisi } \\
\text { Aktual }\end{array}$ & Nilai \\
\hline Bukaan harus dilindungi, & Tidak & C \\
diberi penyetop api. & terdapat & $(75)$ \\
Bukaan vertikal dari & Tidak & \\
dinding tertutup dari & terdapat & \\
bawah sampai atas di & penutup api \\
setiap lantai diberi penutup & & \\
api. & & \\
Sarana proteksi pada & Telah sesuai \\
bukaan meliputi:Pintu & dengan \\
kebakaran, jendela & standar dan \\
kebakaran, pintu penahan & pintu \\
asap dan penutup api & berputar \\
sesuai dengan standar & kesatu \\
Daun pintu dapat berputar & sisi,mampu \\
ke satu sisi Pintu mampu & menahan \\
menahan asap 200 ${ }^{\circ} \mathrm{C}$ Tebal & asap 200 ${ }^{\circ} \mathrm{C}$ \\
daun pintu 35mm & dengan tebal & \\
Jalan keluar/masuk pada & Tingkat \\
dinding tahan api: Lebar & isolasi lebih \\
bukaan pintu keluar harus & dari 30m \\
dari setengah panjang & \\
dinding tahan api Tingkat & \\
isolasi minimal 30 menit. & \\
Jalan keluar/masuk pada & Jalan \\
dinding tahan api & menutup \\
menutup sendiri otomatis & sendiri \\
\hline
\end{tabular}

D) Sarana Penyelamatan

Komponen sarana penyelamatan yang diperiksa di Gedung Menara Bosowa Makassar terdiri atas 2 sub komponen yang meliputi jalan keluar dan konstruksi jalan keluar. Penilaian terhadap kedua sub komponen tersebut akan dijelaskan pada bagian berikut ini.

\section{1) Jalan Keluar}

Penilaian terhadap sub komponen jalan keluar dilakukan dengan pengamatan langsung dan pengukuran menggunakan alat bantu meteran. Hasil penilaian terhadap sub komponen jalan keluar Gedung Menara Bosowa Makassar akan dijelaskan dalam tabel berikut ini. 
Tabel 4. 39 Hasil Pemenuhan Kriteria Jalan Keluar

\begin{tabular}{|c|c|c|}
\hline Kriteria Penilaian & Kondisi Aktual & Nilai \\
\hline $\begin{array}{l}\text { Minimal per lantai } 2 \\
\text { exit dengan tinggi }\end{array}$ & $\begin{array}{l}\text { Telah tersedia } 2 \\
\text { exit dengan tinggi }\end{array}$ & $\begin{array}{c}\mathrm{B} \\
(90)\end{array}$ \\
\hline efektif $2,5 \mathrm{~m}$ & 2,1 meter & \\
\hline $\begin{array}{l}\text { Exit terlindung dari } \\
\text { bahaya kebakaran. }\end{array}$ & $\begin{array}{l}\text { Terlindungi dari } \\
\text { bahaya kebakaran. }\end{array}$ & \\
\hline Jarak tempuh minimal & Terdapat satu titik & \\
\hline $20 \mathrm{~m}$ dari pintu keluar. & $\begin{array}{l}\text { dengan jarak } \\
\text { tempuh } 20 \mathrm{~m} .\end{array}$ & \\
\hline $\begin{array}{l}\text { Ukuran minimal } 200 \\
\mathrm{~cm} .\end{array}$ & $\begin{array}{l}\text { Ukuran lebar jalan } \\
>2 \mathrm{~m} \text {. }\end{array}$ & \\
\hline $\begin{array}{l}\text { Jarak dari suatu exit > } \\
6 \mathrm{~m} .\end{array}$ & $\begin{array}{l}\text { Jarak dari suatu } \\
\text { exit }<6 \mathrm{~m} \text {. }\end{array}$ & \\
\hline $\begin{array}{l}\text { Pintu dari dalam tidak } \\
\text { dibuka langsung ke } \\
\text { tangga. }\end{array}$ & $\begin{array}{l}\text { Pintu dari dalam } \\
\text { tidak dibuka } \\
\text { langsung ketangga. }\end{array}$ & \\
\hline $\begin{array}{l}\text { Penggunaan pintu } \\
\text { ayun tidak }\end{array}$ & $\begin{array}{l}\text { Penggunaan pintu } \\
\text { ayun tidak }\end{array}$ & \\
\hline $\begin{array}{l}\text { mengganggu proses } \\
\text { jalan keluar. }\end{array}$ & $\begin{array}{l}\text { mengganggu } \\
\text { proses jalan keluar. }\end{array}$ & \\
\hline Tersedia lobby bebas & Tidak terdapat & \\
\hline asap TKA 60/60/60 & lobby bebas asap & \\
\hline terdapat pintu keluar & dengan TKA & \\
\hline diberi tekanan positif. & $60 / 60 / 60$ & \\
\hline $\begin{array}{l}\text { Exit tidak boleh } \\
\text { terhalang. }\end{array}$ & $\begin{array}{l}\text { Exit tidak } \\
\text { terhalang. }\end{array}$ & \\
\hline $\begin{array}{l}\text { Exit menuju ruangan } \\
\text { terbuka. }\end{array}$ & $\begin{array}{l}\text { Exit menuju ruang } \\
\text { terbuka. }\end{array}$ & \\
\hline
\end{tabular}

Dari seluruh kriteria penilaian subkomponen jalan keluar, hanya kriteria ketersediaan lobby bebas asap yang tidak terpenuhi.

"...kalau lobby bebas asap, Gedung Menara Bosowa tidak ada..." (ip)

2) Konstruksi Jalan Keluar

Hasil penilaian terhadap subkompomponen konstruksi jalan keluar Gedung Menara Bosowa Makassar akan dijelaskan dalam tabel beirkut ini :
Tabel 4. 40 Hasil Pemenuhan Kriteria Konstruksi Jalan Keluar

\begin{tabular}{llc}
\hline \multicolumn{1}{c}{ Kriteria Penilaian } & \multicolumn{1}{c}{ Kondisi Aktual } & Nilai \\
\hline Konstruksi tahan & Konstruksi beton, & B \\
minimal 2 jam. & tahan diatas 2 jam. & (100) \\
Bebas halangan. & Bebas halangan. \\
Lebar minimal 200 & Lebar jalan keluar \\
cm. & 2m. \\
Jalan terusan yang & Jalan terusan \\
terlindungi terhadap & terlindungi dari \\
kebakaran, bahan & bahaya kebakaran. \\
tidak mudah terbakar, & \\
langit-langit punya & \\
ketahanan penjalaran & \\
api tidak dibawah 60 & \\
menit. & \\
Pada tingkat tertentu & Struktur dari beton \\
elemen bangunan bisa & masih dapat \\
mempertahankan & mempertahankan \\
stabilitas struktur bila & stabilitas struktur \\
terjadi kebakaran. & bangunan. \\
Dapat mencegah & Dapat mencegah \\
penjalaran asap & penjalaran asap \\
kebakaran. & \\
Cukup waktu untuk & Cukup waktu \\
mengevakuasi & untuk \\
penghuni. & mengevakuasi. \\
Akses ke bangunan & Akses ke \\
harus disediakan bagi & bangunan \\
tindakan petugas & disediakan bagi \\
kebakaran. & petugas kebakaran. \\
\hline & \\
\hline
\end{tabular}

\section{3) Landasan Helikopter}

Landasan helikopter merupakan sub komponen yang harus dinilai dalam komponen sarana penyelamatan. Kriteria penilaian sub komponen landasan helikopter berlaku jika bangunan yang diteliti memiliki tinggi minimal 60 meter.

Berdasarkan hasil telaah dokumen layout Gedung Menara Bosowa Makassar, Gedung Menara Bosowa Makassar hanya memiliki tinggi sekitar 102.5 meter sehingga persyaratan landasan helikopter perlu. Tetapi berdasarkan pengamatan dilapangan gedung Menara bosowa tidak memiliki landasan helikopter. 
4. Nilai Keandalan Sistem Keselamatan Bangunan (NKSKB)

Penilaian keandalan sistem keselamatan bangunan berdasarkan pada kriteria dan pembobotan pada yang telah disajikan.

a) Sistem Kelengkapan Tapak

Berdasarkan penelitian yang berjudul "Analisis Penerapan Sarana Penyelamatan dan Sistem Proteksi Pasif terhadap Bahaya Kebakaran (studi kasus : Gedung Menara Bosowa)" yang dilakukan oleh penulis, hasil pengamatan mengenai kelengkapan tapak di Gedung Menara Bosowa Makassar, dapat disajikan dalam tabel berikut :

Tabel 4.43. Hasil Analisis Penilaian Komponen Kelengkapan Tapak

\begin{tabular}{|c|c|c|c|c|c|c|}
\hline No. & $\begin{array}{c}\text { KSKB } \\
\text { /SUB } \\
\text { KSKB } \\
\end{array}$ & $\begin{array}{c}\text { Hasil } \\
\text { Penilaian }\end{array}$ & $\begin{array}{c}\text { Standar } \\
\text { Penilaian }\end{array}$ & Bobot & $\begin{array}{l}\text { Nilai } \\
\text { Kondisi }\end{array}$ & $\begin{array}{l}\text { Jml } \\
\text { Nilai }\end{array}$ \\
\hline 1 & 2 & 3 & 4 & 5 & 6 & 7 \\
\hline \multicolumn{4}{|c|}{ Kelengkapan Tapak } & 25 & & \\
\hline $\begin{array}{l}1 \\
.\end{array}$ & $\begin{array}{l}\text { Sumber } \\
\text { Air }\end{array}$ & B & 100 & 27 & 6.75 & \\
\hline $\begin{array}{l}2 \\
.\end{array}$ & $\begin{array}{l}\text { Jarak } \\
\text { Lingkun } \\
\text { gan } \\
\text { Jarak }\end{array}$ & B & 100 & 25 & 6.25 & \\
\hline $\begin{array}{l}3 \\
.\end{array}$ & $\begin{array}{l}\text { antar } \\
\text { banguna } \\
\mathrm{n}\end{array}$ & B & 100 & 23 & 5.75 & \\
\hline \multirow[t]{2}{*}{$\begin{array}{l}4 \\
.\end{array}$} & $\begin{array}{l}\text { Hidran } \\
\text { halaman }\end{array}$ & B & 100 & 25 & 6.25 & \\
\hline & & & & & Jumlah & 25.00 \\
\hline
\end{tabular}

Berdasarkan Tabel 4.47 diatas jumlah nilai kondisi komponen kelengkapan tapak sebesar $25 \%$ dengan nilai bobot kelengkapan tapak $25 \%$.

\section{b) Sarana Penyelamatan}

Hasil analisis komponen sarana penyelamatan di Gedung Bosowa Makassar, dapat disajikan pada tabel berikut
Tabel 4.44. Hasil Analisis Penilaian Komponen Sarana Penyelamatan

\begin{tabular}{|c|c|c|c|c|c|c|}
\hline No & $\begin{array}{c}\text { KSKB/ } \\
\text { SUB } \\
\text { KSKB }\end{array}$ & $\begin{array}{c}\text { Hasil } \\
\text { Penilaian }\end{array}$ & $\begin{array}{l}\text { Standar } \\
\text { Penilaian }\end{array}$ & $\begin{array}{c}\text { Bobo } \\
\mathbf{t}\end{array}$ & $\begin{array}{c}\text { Nilai } \\
\text { Kondisi }\end{array}$ & $\begin{array}{l}\text { Jml } \\
\text { Nilai }\end{array}$ \\
\hline 1 & 2 & 3 & 4 & 5 & 6 & 7 \\
\hline \multicolumn{4}{|c|}{ Sarana Penyelamatan } & 25 & & \\
\hline 1 & $\begin{array}{l}\text { Jalan } \\
\text { keluar }\end{array}$ & B & 90 & 38 & 8.55 & \\
\hline 2 & $\begin{array}{l}\text { Kons jalan } \\
\text { keluar }\end{array}$ & B & 100 & 35 & 8.75 & \\
\hline \multirow[t]{2}{*}{3} & $\begin{array}{l}\text { Landasan } \\
\text { Helikopter }\end{array}$ & K & 0 & 27 & 0 & \\
\hline & & & & \multicolumn{2}{|c|}{ Jumlah } & 17.30 \\
\hline
\end{tabular}

Berdasarkan Tabel 4.48 diatas jumlah nilai kondisi komponen sarana penyelamatan sebesar $17,30 \%$ dengan nilai bobot sarana penyelamatan $25 \%$.

\section{c) Sistem Proteksi Aktif}

Berdasarkan penelitian yang berjudul "Analisis Penerapan Sistem Proteksi terhadap Bahaya Kebakaran (studi kasus : Gedung Menara Bosowa)" yang dilakukan oleh penulis, hasil pengamatan mengenai sistem proteksi aktif disajikan dalam tabel berikut :

Tabel 4. 41 Hasil Analisis Penilaian Komponen Sistem Proteksi Aktif

\begin{tabular}{|c|c|c|c|c|c|c|}
\hline No & $\begin{array}{c}\text { KSKB /SUB } \\
\text { KSKB }\end{array}$ & $\begin{array}{c}\text { Hasil } \\
\text { Penilaia } \\
\mathbf{n}\end{array}$ & $\begin{array}{l}\text { Standar } \\
\text { Penilaian }\end{array}$ & Bobot & $\begin{array}{c}\text { Nilai } \\
\text { Kondis } \\
\text { i }\end{array}$ & $\begin{array}{c}\text { Jumlah } \\
\text { Nilai }\end{array}$ \\
\hline 1 & 2 & $\mathbf{3}$ & 4 & 5 & 6 & 7 \\
\hline \multicolumn{2}{|c|}{ Sistem Proteksi Aktif } & & & 24 & & \\
\hline 1. & $\begin{array}{l}\text { Deteksi dan } \\
\text { Alarm }\end{array}$ & B & 100 & 8 & 1,92 & \\
\hline 2. & $\begin{array}{l}\text { Siamese } \\
\text { connection }\end{array}$ & B & 100 & 8 & 1,92 & \\
\hline 3. & $\begin{array}{l}\text { Pemadam api } \\
\text { ringan }\end{array}$ & B & 100 & 8 & 1,92 & \\
\hline 4. & $\begin{array}{l}\text { Hidran gedung } \\
\text { (pipa tegak) }\end{array}$ & B & 100 & 8 & 1,92 & \\
\hline 5. & Sprinkler & B & 100 & 8 & 1,92 & \\
\hline 6. & $\begin{array}{l}\text { Sistem } \\
\text { pemadam } \\
\text { luapan }\end{array}$ & B & 100 & 7 & 1,68 & \\
\hline 7. & Pengendali asap & B & 100 & 8 & 1,92 & \\
\hline 8. & Deteksi asap & B & 90 & 8 & 1,73 & \\
\hline 9. & $\begin{array}{l}\text { Pembuangan } \\
\text { asap }\end{array}$ & B & 100 & 7 & 1,68 & \\
\hline 10. & $\begin{array}{l}\text { Lift kebakaran } \\
\text { Cahava darurat }\end{array}$ & $\mathrm{K}$ & 0 & 7 & 0 & \\
\hline 11. & $\begin{array}{l}\text { dan } \\
\text { petunjuk arah }\end{array}$ & B & 100 & 8 & 1,92 & \\
\hline 12. & $\begin{array}{l}\text { Listrik darurat } \\
\text { Ruang }\end{array}$ & B & 90 & 8 & 1,73 & \\
\hline 13. & $\begin{array}{l}\text { pengendali } \\
\text { operasi }\end{array}$ & B & 100 & 7 & 1,68 & \\
\hline & & & & & Jumlah & 21,94 \\
\hline
\end{tabular}


Berdasarkan Tabel 4.49 diatas jumlah nilai kondisi komponen sistem proteksi aktif sebesar 21,94\% dengan nilai bobot sistem proteksi aktif $24 \%$.

\section{d) Sistem Proteksi Pasif}

Prosedur penilaian komponen sistem proteksi pasif sama dengan prosedur penilaian komponen sarana penyelamatan yang membedakan adalah nilai bobot komponen sistem proteksi pasif . Hasil Analisis Penerapan Sistem Proteksi terhadap Bahaya Kebakaran (studi kasus : Gedung Menara Bosowa) dapat disajikan dalam tabel berikut :

Tabel 4. 42 Hasil Analisis Penilaian Komponen Sistem Proteksi Pasif

\begin{tabular}{|c|c|c|c|c|c|c|}
\hline No. & $\begin{array}{c}\text { Komponen } \\
\text { Utilitas/Variabel }\end{array}$ & $\begin{array}{c}\text { Hasil } \\
\text { Penilaia } \\
\mathbf{n}\end{array}$ & $\begin{array}{l}\text { Standar } \\
\text { ?enilaian }\end{array}$ & Bobot & $\begin{array}{c}\text { Nilai } \\
\text { Kondisi }\end{array}$ & $\begin{array}{c}\text { Jumlah } \\
\text { Nilai }\end{array}$ \\
\hline 1 & 2 & 3 & 4 & 5 & 6 & 7 \\
\hline \multicolumn{2}{|c|}{ Sistem Proteksi Pasif } & & & 26 & & \\
\hline \multirow{2}{*}{\multicolumn{2}{|c|}{$\begin{array}{l}\text { Ketahanan api } \\
\text { struktur Bangunan } \\
\text { 2. } \begin{array}{l}\text { Kompartemenisasi } \\
\text { ruang }\end{array}\end{array}$}} & B & 100 & 36 & 9,36 & \\
\hline & & B & 100 & 32 & 8,32 & \\
\hline \multirow[t]{2}{*}{3.} & $\begin{array}{l}\text { Perlindungan } \\
\text { bukaan }\end{array}$ & $\mathrm{C}$ & 75 & 32 & 6,24 & \\
\hline & & & & & Jumlah & 23,92 \\
\hline
\end{tabular}

Berdasarkan Tabel 4.50 diatas jumlah nilai kondisi komponen sistem proteksi pasif sebesesar $23,92 \%$ dengan nilai bobot sistem proteksi pasif $26 \%$.

\section{e) Evaluasi Nilai Keandalan Sistem Keselamatan \\ Bangunan (NKSKB)}

Berdasarkan hasil dari perhitungan nilai keandalan untuk tiap komponen utilitas, dapat disimpulkan dalam bentuk tabel sebagai berikut :

Tabel 4.47. Hasil Perhitungan Penilaian Komponen Utilitas

\begin{tabular}{clcc}
\hline No. & Parameter KSKB & Nilai & $\begin{array}{c}\text { Bobot } \\
\text { KSKS }(\%)\end{array}$ \\
\hline 1 & Kelengkapan Tapak & 25.00 & 25 \\
2 & Sarana Penyelamatan & 17.30 & 25 \\
3 & Sistem Proteksi aktif & 21.94 & 24 \\
4 & Sistem Proteksi Pasif & 23.92 & 26 \\
& NKSKB (\%) & $\mathbf{8 8 . 1 6}$ & $\mathbf{1 0 0}$ \\
\hline
\end{tabular}

Berdasarkan Tabel 4.51 Hasil perhitungan penilaian komponen utilitas menghasilkan Nilai Keandalan Sistem Keselamatan Bnagunan (NKSKB) sebesar $88.16 \%$, hal ini menunjukkan bahwa nilai keandalan bangunan Gedung Menara Bosowa termasuk baik.

\section{Kesimpulan dan Saran}

\section{A. Kesimpulan}

Berdasarkan hasil analisis dan pembahasan data penelitian dapat disimpulkan bahwa :

1. Penerapan sarana penyelamatan dan sistem proteksi pasif terhadap bahaya kebakaran di Gedung Menara Bosowa berdasarkan Peraturan Menteri Pekerjaan Umum 26/PRT/M/2008 mendapatkan hasil penelitian sarana penyelamatan dengan jumlah rata - rata sebesar 5.00 dalam skala likert dan sistem proteksi pasif di Gedung Menara Bosowa meng hasilkan jumlah rata - rata sebesar 5.00 dalam skala likert. Hal ini menunjukkan sarana penyelamatan dan sistem proteksi pasif di Gedung Menara Bosowa telah sangat sesuai dengan Peraturan Menteri Pekerjaan Umum 26/PRT/M/2008.

2. Nilai keandalan sistem keselamatan bangunan terhadap bahaya kebakaran di Gedung Menara Bosowa dengan mengevaluasi penerapan sistem proteksi kebakaran berdasarkan Pd-T-11-2005-C departemen pekerjaan umum mendapatkan hasil penelitian penilain kondisi komponen sistem kelengkapan tapak $25 \%$, Sarana penyelamatan $17,30 \%$, Sistem proteksi aktif 21,94\%, Sistem proteksi pasif $23,92 \%$, dari seluruh komponen diperoleh total nilai kondisi sebesar $88,16 \%$ dari skala $100 \%$. Hal ini menunjukkan bahwa Nilai Keandalan Sistem Keselamatan Bangunan (NKSKB) telah sangat sesuai dengan peraturan PdT-11-2005-C.

\section{B. Saran}

Berdasarkan pada hasil penelitian, terdapat beberapa saran yang diharapkan dapat menjadi masukan guna meningkatkan kualitas sistem keselamatan bangunan di Gedung Menara Bosowa Makassar. Adapun saransaran tersebut adalah sebagai berikut :

1. Bagi pihak yang berwenang menangani semua yang berhubungan dengan Sistem Proteksi Kebakaran di Gedung Menara Bosowa Makassar, diharapkan dapat melengkapi dan meningkatan kualitas Sistem Proteksi Kebakaran terutama jumlah perlindungan bukaan, mengingat bangunan tersebut memiliki tingkat 23 lantai. 
2. Bagi kalangan akademis yang ingin melakukan penelitian mengenai kualitas Sistem Proteksi Kebakaran diharapkan sebagai bahan pertimbangan peningkatan kualitas Sistem Proteksi Kebakaran terhadap bahaya kebakaran gedung di Indonesia khususnya bagi gedung yang berkaitan erat dengan aktivitas banyak orang seperti halnya apartemen, mall ataupun rumah sakit. Dengan demikian diharapkan resiko terhadap bahaya kebakaran dapat dihindari dan diantisipasi.

\section{Daftar Pustaka}

[1] Christiani P, Lily. 2011. "Analisis Pelaksanaan Fire Planning Management Pada Hotel di Surakarta" Universitas Sebelas Maret, Surakarta.

[2] Fajar, Ihwan. Jumlah Kebakaran di Makassar Meningkat (online), https://kabar.news/2018-jumlah-kebakaran-dimakassar-meningkat. Diakses tanggal 5 Agustus 2019.

[3] Hesna, Yervi, Benny Hidayat, dan Satria Suwanda. 2009. Evaluasi Penerapan Sistem Keselamatan Kebakaran Pada Bangunan Gedung Rumah Sakit Dr. M. Djamil Padang. Rekayasa Sipil, 18(2).

[4] Indra Wijaya, Dwiyoga Noris. 2011. "Analisis Keandalan Bangunan (Studi Kasus Bangunan Laboratorium Teknik Fakultas Teknik Universitas Sebelas Maret Surakarta)" Universitas Sebelas Maret, Surakarta.

[5] Klasifikasi Kebakaran Menurut NFPA (online). http://lib.ui.ac.id/file?file=digital/125291-S-5708-
Audit\%20keselamatan-Literatur.pdf. Diakses tanggal 7 Agustus 2019.

[6] Parwitasari, Rr Aryu Diah. 2010. “Analisis Tingkat Kepentingan dan Persepsi Pengguna Bangunan Terhadap Fire Planning Management Rumah Sakit di Kota Surakarta", Universitas Sebelas Maret, Surakarta.

[7] Peraturan Menteri Pekerjaan Umum Nomor 26/PRT/M/2008. 2008. Persyaratan Teknis Sistem Proteksi Kebakaran Pada Bangunan Gedung dan Lingkungan. Jakarta.

[8] Peraturan Menteri Tenaga Kerja dan Transmigrasi RI Nomor 04/Men/1980. 1980. Syarat-syarat Pemasangan dan Pemeliharaan Alat Pemadam Api Ringan. Jakarta.

[9] Ramli, Soehatman. 2010. "Pedoman Praktis Manajemen Risiko dalam Prespektif K3". Jakarta: Dian Rakyat.

[10] ----2010. "Sistem Manajemen Keselamatan dan Kesehatan Kerja OSHAS 18001”. Jakarta: Dian Rakyat.

[11] Republik Indonesia. 2004. Peraturan Daerah Kota Makassar Nomor 15 Tahun 2004 tentang Tata Bangunan. Lembaran Daerah Kota Makassar Tahun 2004, No. 9. Sekretariat Daerah Kota Makassar. Makassar.

[12] Republik Indonesia. 2002. Undang-Undang Nomor 28 Tahun 2008 tentang Bangunan Gedung. Lembaran RI Tahun 2002, No. 134. Sekretariat Negara. Jakarta.

[13] Saptaria, E., Mulyanto, S., dan Maryono. 2006. Pemeriksaan Keselamatan Kebakaran Bangunan Gedung, Badan Litbag PU Departemen Pekerjaan Umum, Pd-T-11-2005-C. Jakarta.

[14] Standar Nasional Indonesia. 2000. Tata Cara Perencanaan Sistem Proteksi Pasif Untuk Pencegahan Bahaya Kebakaran Pada Bangunan Gedung, SNI 03-1736-2000. Jakarta: BSNI.

[15] Sugiyono. 2009. "Metode Penelitian Kuantitatif dan Kualitatif dan Research and Development”. Bandung: CV. Alfabeta. 